Bernhard Wälchli*

\title{
The morphologization of negation constructions in Nalca (Mek, Tanah Papua), or, how nothing easily moves to the middle of a word
}

\author{
https://doi.org/10.1515/ling-2018-0027
}

\begin{abstract}
The Mek language Nalca has undergone a rapid synthetization of verbal negation by way of two successive stages of asymmetric negation, the first one involving referential zeroing with a verbal noun, the second one reintroducing person marking with an auxiliary in analogy to non-verbal predicates. This development can be traced in texts in the more conservative closely related Mek language Eipo. Referential zeroing originally had the connotation of absolute negation (more than the denial of one specific event). As Nalca negation was integrated into inflectional morphology, it developed some of the hallmarks of autonomous morphology - morphomes and empty morphs. Nalca negation illustrates how grammaticalization and analogy can go hand-in-hand. The fusion of verbal negation is a case of the morphologization of a construction which does not occur in isolation but in concert with other similar processes, together entailing a fragmentation of negation marking. Finally, the Nalca development shows that cases of fusion of verbal negation must be taken into account when dealing with the interplay of existential negation and verbal negation in terms of cyclic processes.
\end{abstract}

Keywords: negation, Nalca, Mek languages, existential, verbal noun, prohibitive, morphome, synthesis, grammaticalization, analogy, historical linguistics

\section{Introduction}

While most Mek languages (Trans New Guinea phylum, Tanah Papua) have analytic sentence negation with a particle preposed (Eipo gum V-INFL, Una kum V-INFL) or postposed to the inflected verb (Yale V-INFL kom), Nalca has "moved" negation to the middle of the inflected verb: Nalca V- $\eta g u$-INFL written as $\langle\mathrm{V}$-nggu-INFL $\rangle$. This is illustrated in (1)-(3), where it can be seen from the identical root $l e(b)$ - 'speak' and the habitual/durative/imperfective suffix -lam-

*Corresponding author: Bernhard Wälchli, Department of Linguistics, Stockholm University, Stockholm SE-10691, Sweden, E-mail: bernhard@ling.su.se

Ә Open Access. (c) 2018 Wälchli, published by De Gruyter. (c) BY-NC-ND This work is licensed under the Creative Commons Attribution-NonCommercial-NoDerivatives 4.0 License. 
that the Mek languages are very closely related genealogically. Eipo and Yale have been well documented by Volker Heeschen; the material used for Nalca in this paper is taken primarily from the translation of the New Testament.

(1) Eipo: symmetric negation, free, preposed negation marker Isa-nang-tam ara, lik yupe gum le-lam-ak. spirit-people-side TOP lik word NEG speak-HAB-PRS.3PL 'As to the side of the spirits, they do not speak the lik (Eipo) language.' (Heeschen 1998: 178)

(2) Yale: symmetric negation, free, postposed negation marker

Yubu leb-so-nge le-lam-la kom.

word speak-POT.3SG-NMLZ say-DUR-PRS.3SG NEG.

'He does not say what he is obliged to.'

(Heeschen 1992a: 35)

(3) Nalca: symmetric negation, bound, imperfective aspect

Na-ra ban weny-a-la-na-nya ne-ra dib le-lem-na, 1SG-TOP DEM thus-say-IPFV-PRS.1SG-NMLZ N-TOP right speak-IPFV-PRS.1SG sonda a-k le-nggu-lum-na.

false DP-DAT speak-NEG-IPFV-PRS.1SG

'I am speaking the truth, I am not lying.'

(N.T. 54002007) ${ }^{1}$

The morphologization of Mek negation constructions in Nalca is the topic of this article and it will be shown that it is remarkable in several respects, notably by:

(i) the rapid grammaticalization of synthetic sentence negation from analytic sentence negation by way of asymmetric marking strategies,

(ii) the possibility to identify the semantic niche (absolute negation) where the grammaticalization process started (Section 3),

(iii) the emergence of autonomous morphological phenomena (Section 4),

(iv) the interplay of grammaticalization and analogy (Sections 3 and 4),

(v) the loss of a general negation marker and the concomitant development of several different negation morphemes for non-standard negation (Section 5),

(vi) the interaction of these developments with Croft's existential negation cycle (Section 6).

$154-002-007$ is Chapter 2, Verse 7 in Book 54, which is Timothy 1. Matthew, the first book of the N.T., is $40-$. 
In Nalca a new synthetic negation morpheme /-ngu-/ arises from the fusion (also called amalgamation or merger) of an analytic construction with the verbal noun (suffix $-n(a)$ ), the negation particle gom and the auxiliary $u(b)$ - 'be, live' (V-na gom $u$-INFL $>$ V- $\eta g u$-INFL). This is a textbook case of Lüdtke's quantitative language change (Lüdtke 1980a, 1980b): accumulation of morphemes plus phonological reduction plus deletion of morpheme boundaries, which is a basic mechanism in grammaticalization (Meillet 1948 [1912]); (Haspelmath 1998: 318). In grammaticalization, morphemes do not easily move to the middle of a word, but they can easily be dragged along by auxiliaries to what becomes the middle of a word after fusion has taken place. Hereby, verbal negation in Nalca ends up in a typologically expected position. According to Bybee (1985: 178), following Dahl (1979), negation is a category where position with regard to other categories tends to be determined in an absolute left-to-right fashion, which means that the position immediately after the stem is preferred if negation is a suffix. As we will see below, the auxiliary is originally introduced in analogy to other non-finite predicates. From the unidirectionality of grammaticalization processes ("today's morphology is yesterday's syntax", Givon 1971) we can predict that the synthetic form must be secondary, if the morphemes are cognate.

In Mek we cannot only reconstruct a grammaticalization of synthetic sentence negation, we can also understand how it developed step by step thanks to Volker Heeschen's excellent collections of Eipo original texts. In Eipo texts, verbal nouns followed by the negation particle as in (4) are very common. This is basically a variant of the Eipo negative existential construction $N$ gum 'N does not exist'. But o-ne gum [kill-VN NEG] has acquired a wider meaning than 'there is no killing'. It usually expresses impossibility, negative habitual or prohibitive, or, more generally, absolute negation (more than just the denial of one specific event). The subject in (4) is not overtly expressed, but retrieved from the context, here the preceding clause. Absolute negation is a stronger, more emphatic form of negation, cannot kill implies does not kill, but not vice versa.

(4) Eipo: absolute negation with referential zeroing

Da=bi-n-m-uk=ine, basam ton o-ne gum.

here=go-REP-DUR-PST.3SG=while pig one kill-vN NEG

'While he went around here and there, there was no killing of a pig (=he did not kill, was not able to kill a pig).'

(Heeschen 2015: 225, No. 21)

From a typological perspective, analytic standard negation in Eipo and Yale and synthetic (imperfective) negation in Nalca are similar in that they both reflect symmetric negation where there is "no further formal structural differences in 
comparison to the corresponding affirmative” (Miestamo 2005: 1). However, the grammaticalization from a construction with a verbal noun and an auxiliary presupposes an asymmetric stage where "further formal structural differences can be found" (Miestamo 2005: 7), more precisely the A/Fin asymmetric type where "the lexical verb loses its finiteness, and usually a new finite element (auxiliary) is introduced" (Miestamo 2005: 73).

The Nalca Example (3) suggests that grammaticalization simply reintroduced symmetry in Nalca. However, grammaticalization can motivate the development of symmetric synthetic negation only in the Nalca imperfective. This is because Mek verbs have different stems in different tense-aspect forms. If there had been only grammaticalization, all negative forms would use the imperfective stem and only imperfective negation would be symmetric. However, Nalca has reintroduced the perfective stem in negative forms used in perfective aspect and future tense by analogy, which makes the future and perfective forms symmetric (at least as far as stems are concerned), as can be seen in Table 1 for the verb $b i$-/ba- 'go'. Only the perfect stem has not been extended to the negative, so that the negative perfect remains asymmetric. This synchronically strange and typologically idiosyncratic pattern is a morphomic split. According to Corbett (2016: 64), splits in inflectional paradigms may be motivated, that is they may correspond to morphosemantic, morphosyntactic, or phonological specifications, or they may lack such motivation, in which case we have a morphomic split.

Table 1: Idiosyncratic distribution of stems in the Nalca verb 'go'.

\begin{tabular}{lllllll}
\hline Verbal noun & & Imperfective & Perfective & Future & Perfect \\
\hline ba-na' & AFFIRMATIVE: & ba-lam- & bi-/by- & bi-nim- & bili(-m)- \\
\cline { 6 - 7 } & NEGATIVE: & ba-nggu-lum- & bi-nggu-b- & bi-nggu-num- & bi-nggu(-m)- \\
\hline
\end{tabular}

The term "morphomic split" derives from the notion of "morphome" coined by Mark Aronoff. A morphome (Aronoff 1994; Maiden 2005) is a phonologically and morphosyntactically incoherent morph, i.e. a segment of a word whose form and distribution within the paradigm defies phonological generalization and whose pattern is irreducible to any natural morphosyntactic class. A classic example for a morphome is the so-called L-pattern in Spanish and Portuguese verbs, which covers a set of forms which do not form a natural morphosyntactic class together: the subjunctive of all persons plus the first person singular indicative. The L-pattern with the morphomic stem poss- in the verb 'can' in Table 2 (as opposed to the stem pod-in the other cells) illustrates that the L-pattern is an 
Table 2: L-pattern (boldface) in Portuguese illustrated with the verb 'can' (Maiden 2005: 149).

\begin{tabular}{lllllll}
\hline & 1SG & 2SG & 3SG & 1PL & 2PL & 3PL \\
\hline Indicative & posso & podes & pode & podemos & podeis & podem \\
\cline { 5 - 8 } Subjunctive & possa & possas & possa & possamos & possais & possam \\
\hline
\end{tabular}

attractor since the first person plural is an innovation in this verb diachronically (Latin possumus 'we can') in analogy to other verbs displaying the L-pattern.

Morphomes are a highly controversial notion; see the papers in Luís and Bermúdez-Otero (2016a) for a wide range of views. Luís et al. (2016b: 319) point out that the existence of morphomes is difficult to prove since their definition is purely negative, but, as shown by Corbett (2016), morphomic splits can be clearly distinguished from motivated splits in inflectional paradigms. I will argue in Section 4 that the development of a morphomic split is hardly avoidable when Nalca negation becomes synthetic. The fusion of negation is a morphome trap in which Nalca negation is caught. Put differently, a morphomic split develops and is maintained because a motivated split is out of reach unless the system would be completely restructured.

While Romance verbs have morphomes in idiosyncratic sets of personnumber and mood forms, Nalca has morphomes in idiosyncratic sets of tenseaspect and polarity forms. The Nalca negative perfect has the same stem as the perfective and the future, but the negative perfect does not form a natural morphological class together with the perfective and future and the set of forms sharing the same stem (including some non-finite forms not listed in Table 1 to be discussed in Section 4) is not phonologically conditioned. In Section 4 it will be shown that the idiosyncratic distribution is not a diachronic relic, but the result of diachronic innovations, which presuppose the psychological reality of morphomes in the same way as in Romance verbs.

Fusion had major consequences for negation beyond verbal standard negation. While Eipo has a general negation morpheme, the particle gum, Nalca - $\eta g u$ is limited to finite verbs, since it is a fusion of the verbal negation construction consisting originally of verbal noun + negation + auxiliary. Negation constructions either lacking a verbal noun or finite inflection could not join in in the same grammaticalization process and hence Nalca has developed a whole range of different negation morphemes for the negative existential, the negative potential, the negative converb, and the prohibitive (see Table 3).

With the exception of the Nalca existential negator orok with a lexical source (<'empty'), all Nalca negation morphemes in Table 3 are fusions from constructions with the Mek negation particle gom. No general negation morpheme can be 
Table 3: General negation marker gum in Eipo and fragmented negation markers in Nalca.

\begin{tabular}{llllc}
\hline & Eipo & Nalca & Aux & VN \\
\hline Verbal negation & gum V-INFL & V-nggu-INFL & + & + \\
Neg existential & N gum (u-INFL) & N orok & $-/+$ & - \\
Neg potential & V-(DUR-)VN gum $(u$-INFL) & V-(na)menggom & - & + \\
Neg converb & gum V-CVB & V-nggonggom & - & + \\
Prohibitive & V-VN gum & V-nggom (mem) & - & + \\
& V-VN mem & V-VN TOP mem & & \\
\hline
\end{tabular}

segmented in Nalca even though all forms except the existential negator orok are similar in form.

The rest of this paper is structured as follows. Section 2 provides background information on the Mek family. Section 3 explores the semantic niche that has triggered grammaticalization in Nalca in Eipo and Yale material. Section 4 shows how autonomous morphological phenomena evolve in Nalca as verbal negation morphologizes. Section 5 discusses how non-standard negation strategies in Nalca have diverged from standard negation as a concomitant development to the narrowing of the standard negation marker. Section 6 discusses the developments in Nalca negation in the context of Croft's (1991) existential negation cycle. Section 7 summarizes the Nalca development and concludes this paper.

\section{Background information: The Mek languages and their documentation}

The Mek languages are spoken in the highlands of Tanah Papua and belong to the Trans New Guinea phylum, but are not closely related to any other Trans New Guinean languages. The Mek languages border the Dani languages to the west and the Ok languages to the east, but are "relatively stable against influences from other languages” (Heeschen 1998: 85). The Glottolog 2.7 (Hammarström et al. 2016) lists eight Mek languages, but only four of them have documentations available to me (Table 4). For Eipo and Yale the major sources are text collections, grammars and dictionaries by Volker Heeschen. For Nalca and Una the major pieces of documentation consist of the translations of the New Testament. There is also a reference grammar for Una (Louwerse 1988) and two grammar sketches for Nalca, Rule et al. (1972) and Svärd (2013), the latter based entirely on the N.T.

This paper argues that Nalca is innovative within Mek in the expression of negation and in this context it is important to point out that Nalca is more 
Table 4: The Mek languages considered in this study.

\begin{tabular}{|c|c|c|c|}
\hline $\begin{array}{l}\text { Yale } \\
\text { (Kosarek) }\end{array}$ & Nalca & Eipo & Una \\
\hline $\begin{array}{l}\text { Heeschen } \\
(1992 a, \\
2000)\end{array}$ & $\begin{array}{l}\text { Rule et al. (1972), } \\
\text { Binzell (n.d.), Svärd } \\
\text { (2013), N.T. }\end{array}$ & $\begin{array}{l}\text { Heeschen (1990), Haspelmath } \\
\text { (1998), 2015); Heeschen and } \\
\text { Schiefenhövel (1983); Eibl- } \\
\text { Eibesfeldt et al. (1989) }\end{array}$ & $\begin{array}{l}\text { Louwerse (1988), } \\
\text { Kroneman (2004), } \\
\text { Heeschen (1992b), } \\
\text { de Vries (2007), N.T. }\end{array}$ \\
\hline
\end{tabular}

progressive in many areas of phonology and grammar than the more conservative eastern languages Eipo and Una (see also Heeschen 1998: 73). The sound change $t>s$ only occurs in western languages and word-initial $k$ - retained in the East is lost in Yale, Nalca and partly Eipo: Una $k u(b)$ - 'be', Eipo, Nalca $u(b)$-. The prenominal demonstrative $a$ is preserved only in Una and partly in Eipo. Unlike other Mek languages Nalca has developed a gender system (Wälchli 2018).

The Mek languages are SOV. Alignment in Nalca and other Mek languages is highly complex. In Nalca, there is differential O (dative, zero, topic), differential $S$ (topic, ergative, dative, zero), and differential A marking (ergative, topic, zero). In personal pronouns, topic is often nominative (A and S; see Svärd 2013: 22), but ergative also occurs (see (23) and (33)).

Mek languages have a complex finite verb with the structure (5), in Nalca with negation (6) as illustrated in (7).

(5) Mek verb structure

Stem-Aspect/Tense-ObjectPerson-SubjectPerson/Number/Tense/Mood

(6) Nalca verb structure

Stem-Negation-Aspect/Tense-ObjectPerson-SubjectPerson/Number/Tense/

Mood

(7) Nalca verb structure

$\begin{array}{lllll}\text { Pam-a } & \text { dobnu- } & n g g u- & n e:- & n g g e:- \\ \text { pig-EMPH } & \begin{array}{l}\text { take[N_IPFV\&]- } \\ \text { NEG- }\end{array} & \text { FUT- } & \text { OBJ.2SG- } \\ & \text { stem- } & \text { negation- } & \text { aspect/tense- } & \text { object- }\end{array}$

PRS.1SG

subject/number/tense/mood

'I will not take the pigs from you.'

Binzell (n.d.) 
Finite tense/aspect forms and non-finite forms have several stem forms. These will play an important role in Section 4. Table 5 lists the most frequent verb types and a few irregular verbs for Nalca with stem forms in the affirmative. Stem forms have not always been as semantically empty in Mek as in Nalca. They have developed at least partly from stem extensions with aspectual meanings (Heeschen 1998: 224-229). Eipo, but not Nalca, has a repetitive stem extension - $n$ - (Eipo o- $n$ - 'hit several times' vs. $o b$ - 'hit once'). In Eipo, the repetitive extension - $n$ - tends to occur especially before the durative tense/aspect suffix -ma- (see Example (4)), which is replaced by -lam- (habitual > imperfective) in Nalca.

Table 5: Nalca verb stems (source: N.T.).

\begin{tabular}{|c|c|c|c|c|c|c|}
\hline Verb type & $\begin{array}{l}\text { IPFV/VN/ } \\
\text { SIM_CVB }\end{array}$ & $\begin{array}{l}\text { PFV/FUT/ } \\
\text { MED }\end{array}$ & PRF & S_CVB & $\begin{array}{l}V_{1}-l V_{2} \\
\text { sequence }\end{array}$ & Meaning \\
\hline (C) $\mathrm{V}(b)-$ & le- & leb- & le- & $l e b-$ & *le-l & 'speak' \\
\hline (C)ei(b/li/yi)- & eilli- & $e i b-$ & eiyi- & $\begin{array}{l}\text { eiyib-, } \\
\text { eiliw- }\end{array}$ & $e i-l$ & 'see' \\
\hline (C) $\mathrm{V} b(e)-$ & gib- & gib- & *gibe- & gib- & gibe-l & 'greet' \\
\hline (C) $\mathrm{V}(k)-$ & bu- & buk- & buku- & buk- & bu-l & 'sit' \\
\hline (C)Vk(e)- & dek- & dek- & deke- & dek- & deke-l & ‘sell/pay' \\
\hline $\begin{array}{l}(\mathrm{C}) \mathrm{VCV}(g a / \\
k)-\end{array}$ & elek- & $\begin{array}{l}\text { elega FUT } \\
\text { eleg(o)- PFV }\end{array}$ & elega/e- & eleg- & elege-l & 'give' \\
\hline (C) VCV(wa)- & sene- & $\begin{array}{l}\text { senewa- FUT } \\
\text { sene- PFV }\end{array}$ & sene- & $\begin{array}{l}\text { senew-, } \\
\text { seneb- }\end{array}$ & senewa-l & 'think' \\
\hline $\begin{array}{l}<{ }^{*} \text {-deib- 'put } \\
\text { down' }\end{array}$ & -(i)lli- & $\begin{array}{l}\text {-(i)yiwa- FUT } \\
\text {-(i)yi PFV }\end{array}$ & -(i)yi- & $\begin{array}{l}\text {-(i)yiw- } \\
\text { (-(i)yib-) }\end{array}$ & -(i)yiwa-l & Causative \\
\hline$d e-$ & de- & de- & de- & dereg- & $d e-l$ & 'eat/drink' \\
\hline da(nga)- & da(nga)- & $d a-$ & danga- & dangaw- & $d a(n g a-) l$ & ‘become’ \\
\hline bi/ba/bili- & $b a-$ & bi-, by- & bili- & binib- & $b a-l$ & 'go' \\
\hline $\begin{array}{c}\text { ya(ngga)/ } \\
\text { yeili- }\end{array}$ & $\begin{array}{l}\text { ya } \\
\text { (ngga)- }\end{array}$ & ya- & yeili- & $\begin{array}{l}\text { yangaw-, } \\
\text { yab-, yeiliw- }\end{array}$ & $y a(n g g a)-l$ & 'come' \\
\hline Suppl. he-/a- & (weny)a- & (weny)he- & (weny)a- & (weny)ab- & wenya-l & 'say' \\
\hline
\end{tabular}

Forms with an asterisk are not attested in the N.T. and reconstructed from other verbs of the same type

The Nalca aspect forms with zero (perfective), -lam (imperfective) and - $m$ (perfect) suffixes all recur in Yale and Eipo. ${ }^{2}$ The future tense marker originally

2 Eipo -lam is habitual, but Nalca and Yale -lam rather correspond to Eipo durative -ma. Eipo - $a m$ is less grammaticalized than Nalca $-m$. It is still more properly a perfect in Eipo, whereas the term "perfect" in Nalca is used only for convenience. It has a more extended meaning in Nalca and is maybe best characterized as a non-punctiliar perfective. In Yale it often expresses a prior action and this also holds for Nalca. 
consists of two slots, future plus aspect. Eipo distinguishes - n-am [FUT-PRF] 'far future', -na-ma [FUT-DUR] 'near future', and -nu [FUT[PFV]] 'near future, volitional' and Yale has -nu-am, -nu-lam and -nu (Heeschen 1992a: 26). In Section 4 we will see that the original near future marker lost in this function in Nalca and was reanalyzed as an empty morph in the potential negation form. In Nalca, it is easiest to consider -nam as a simple future tense morpheme. ${ }^{3}$

The major forms of the subject person/number/tense/mood slot as they can be found in the Nalca N.T. are given in Table $6 .^{4}$ The potential expresses ability and possibility and is mostly combined with the future tense/aspect marker. Sentence-medial forms, as they are characteristic of many Papuan languages, mainly occur before a connector in Mek languages.

Table 6: Person/number/tense/mood suffixes in the Nalca N.T.

\begin{tabular}{|c|c|c|c|c|c|}
\hline & PResent & remote Past & ротеntial & IMPerative & sentence-MEDial \\
\hline $1 \mathrm{SG}$ & $-n a,-n$ & $-s a$ & $-\sin y a$ & & $-n y a$ \\
\hline $2 \mathrm{SG}$ & $-l[a / e]-m$ & -lam & -som & $-10 m$ & -men \\
\hline $3 S G$ & $-1 a,-1$ & $-o k,-u k$ & -so & $-(u) l u l$ & $-l y a$ \\
\hline 1DU & $-n a m$ & -num & $-\operatorname{sinim}$ & & $?$ \\
\hline 2DU & -rum/dum & - rum/dum & -surum & -durum, -ururum & -dumun/-rumun \\
\hline 3DU & $-r a k / d a k$ & -rek/dek & -sereng & & -dek/-rek \\
\hline $1 \mathrm{PL}$ & $-a b$ & $-o u b a$ & -sibya & & -eibya \\
\hline $2 \mathrm{PL}$ & -lum & -lum & -som & -(u)lulum & -mun \\
\hline 3PL & $-a k$ & -ek & -seng & & -ek \\
\hline
\end{tabular}

Different names for various Mek aspect markers

\begin{tabular}{lllll}
\hline & Zero & -lam & $-(\boldsymbol{a}) \boldsymbol{m}$ & $\boldsymbol{- m a}$ \\
\hline This paper & perfective & imperfective & perfect & durative \\
\hline Nalca (Rule et al. 1972) & punctiliar & continuative & completive & - \\
\hline Yale (Heeschen 1992a) & completed & durative & prior action & - \\
\hline Eipo (Heeschen 1998) & perfective, punctiliar & habitual & perfect & durative \\
\hline
\end{tabular}

3 In Nalca there is a rare customary future with future and imperfective marker in reversed order -lam-nam-, and the first person forms of nu- (1SG -nun, 1DU -nurum 1PL -nob) occur in purposive clauses in pseudo-quotative function, but are not attested with negation.

4 There is also a near past restricted to events which happened yesterday (Rule et al. 1972: 43), and a recent past tense - $b$-ma- (“completive"), -l-ma- (“continuative”; Rule et al. 1972: 42) reminiscent of the Eipo durative. Both near past and recent past are very rare in the N.T., so that the remote past is simply glossed P[a]ST in this paper for convenience. 
Mek languages have a variety of non-inflected non-finite verb forms. Two among them are important for the discussion of negation, the verbal noun Eipo $-n a / n e$ (final $-a$ is often weakened to $-e$ in Eipo) and Nalca $-n a^{\prime}$ (glottalized), and the sequential converb Eipo - $u k a$, Nalca -oka. There is also a simultaneous converb Eipo - de/re, Nalca/Yale -do and other less productive converb markers (Yale/Nalca -om anterior). Verbal nouns in Mek languages are not to be confounded with nominalizations, which are sentential (have inflected verbs) and are followed by light nouns such as nang 'people' in generalized noun-modifying clause constructions: "a noun phrase consisting of a head noun and a dependent (modifying) clause, with no explicit indication of the relation between the head noun and the modifying clause" (Comrie et al. 2013). One of their major functions is to express relative clauses. In Nalca sentential nominalizations can also be followed by one of three suffixes: -nya 'man', which takes following masculine gender (be-), homophonous -nya 'thing', which takes following neuter gender (ne-), and $-a^{\prime}$ 'the thing that, the fact that', which takes following default phrase gender $(a$-). The former two suffixes are glossed NMLZ, $-a$ ' is glossed 'thing'.

Nalca nouns and particles often have a suffix $-a$, which sometimes marks emphasis, but is most often phonologically conditioned as it is present when the following word has consonantal onset and absent with following vocalic onset. When separated in glossing, as in (7), it is glossed as EMPH. In 5.2 we will see that this emphatic element plays a role in Nalca negation marking, which is not unexpected as emphatic markers are often involved in negation constructions.

This paper follows the Nalca orthography of the New Testament, which does not mark tone (high and low) or distinctive stress (Rule etal. 1972: 12-15) and disregards the distinction between $/ \mathrm{e} /$ and $/ \varepsilon /$ and between $/ \mathrm{o} /$ and $/ \mathrm{\rho} /$ (Rule et al. 1972 and Binzell (n.d.). use $\langle\mathrm{y}\rangle$ and $\langle\mathrm{e}$ : $>$ for $/ \mathrm{e} /,<\mathrm{e}\rangle$ for $/ \varepsilon /,\langle\mathrm{v}\rangle$ for $/ \mathrm{o} /$, and $\langle 0\rangle$ for $/ \mathrm{J} /$ ). Eipo and Yale have a five vowel system. In Nalca there is a suprasegmental glottal feature on word final consonants marked as '.

\section{Absolute negation and how person marking is first removed and then reintroduced}

Eipo texts (Heeschen 1990, 2015) show that the Nalca fused construction VERBAL NOUN + NEGATOR + AUXILIARY developed in two steps. Eipo is more conservative than Nalca in many respects (see Section 2). The first step in the development is the construction VERBAL NOUN + NEGATOR without person marking with 
its own semantic niche, absolute negation. The second step is the reintroduction of person marking with the auxiliary $u(b)$ - 'be, live'. This section traces the developments.

Mek verbal nouns express events as finite verb forms do, but lack subject person markers. This makes them an ideal device for "referential zeroing" (Heeschen 1998: 259). Aspect/tense and object person markers are optional. The existential negation construction N NEG, illustrated in (8), provides the construction into which verbal nouns can be inserted.

(8) Eipo: existential negation

yo deye buk-m-uk, ukwe gum

tree base sit-DUR-PST.3SG fire NEG

'he was sitting at the tree trunk, there was no fire'

(Heeschen 2015: 150)

The original meaning of gum is 'nothing' (adjective or noun, not an indefinite pronoun), which can be seen in Yale kom da- and Eipo gum da- [NEG/nothing become] 'turn to nothing, be destroyed"5:

(9) Eipo: gum 'nothing'

ninye fi gum da-nam-ak...

man very nothing/NEG become-FAR_FUT-PRS.3PL

'then people will be completely destroyed'

(Heeschen 2015: 150)

The preverbal position in Eipo dominant verbal negation is the normal position for adverbs. Eipo gum is also the short answer 'no'. For the prohibitive Eipo uses the verbal noun followed by gum NEG or the adjective mem 'taboo, forbidden, sacred'. The construction VERBAL NOUN + gum could therefore also be interpreted as predication ' $\mathrm{V}$ is nothing' or as a combination of two clauses 'As to $\mathrm{V}$, no!', which may have boosted its wider use beyond the meaning '[event] does not exist'. The construction VERBAL NOUN + NEGATOR did not immediately compete with standard verbal negation, but first established its own semantic niche: absolute negation. ${ }^{6}$ Absolute negation is more general than the denial of

5 Yale fairy tales are called kom (="nothing"). They often end with komkom "notnot" or "not nothing". Kom means that one does not tell the truth, nobody should feel affected, but everybody tries to understand the truth behind the kom (Volker Heeschen, p.c.).

6 There is a parallel with a different semantic niche in Bantu languages in so-called "postinitial" negation (PERSON-NEG-VERB.STEM) grammaticalizing from negative auxiliary and verbal 
a specific event. Its concrete manifestations are negative habitual, prohibitive and impossibility. (10) from the description of initiation rites with both habitual and prohibitive connotation is a characteristic example:

(10) Eipo: absolute negation

Keting noitam sakalkwote-ne gum, metek bure ba-ne gum... sun middle defecate-vN NEG little outside go-vN NEG

'At noon there was no urination and defecation, they [the boys] were not allowed to go out.'

(Heeschen 1990: 138, line 60)

Absolute negation is generally suitable for the expression of impossibility, but in Eipo it is especially the verbal noun with durative aspect marking that becomes associated with impossibility. As we will see in Sections 4 and 5.2, this construction fuses in Nalca to the negative potential.

(11) Eipo: durative verbal noun in impossibility use

yo taram kisik-nin yanga-n-ma-le=buk,

tree chest push-CVB come[IPFV]-REP-DUR-PRS.3SG=but

fi $\boldsymbol{y} \boldsymbol{a}-\boldsymbol{n}-\boldsymbol{m a} \boldsymbol{n} \boldsymbol{n}$ gum

very come[PFV]-REP-DUR-VN NEG

'she comes pushing along the chest of the tree, but there is no way to pass/ she cannot pass'

(Heeschen 2015: 298, No. 31)

Note that the stem forms before repetitive and durative suffixes vary in (11). In the negated durative verbal noun with impossibility meaning only the perfective stem is used. This detail will turn out to be important for the development of Nalca synthetic negation (Section 4).

In discourse, absolute negation is difficult to keep strictly apart from specific event negation, since absolute negation tends to be associated with a specific event in a concrete context. This is why it is often unclear whether or not the VERBAL NOUN + NEGATOR construction in Eipo and Yale is to be translated with a modal verb. In (12) and (13), Heeschen has opted for not using a modal verb, but still negation can conceived of as absolute here: '(they) will not be able to go to the gardens' and '(they) could not find (the man)'.

noun. Güldemann (1999: 552-564) argues that such constructions originally have the specific meaning that negation is not part of the focal information in the utterance, which makes them prone to develop into negation in non-finite/non-declarative/non-main clauses. 
(12) Yale: referential zeroing in negation

Mak ya-lam-le=ba, aue=ak bi-n kom.

rain come-DUR-PRS.3SG=CONNEC, garden=at/to go-VN NEG

'Because the rain is coming, they will not go to the gardens.'

(Heeschen 1992a: 18)

(13) Eipo: referential zeroing in negation

E-lam-ik-buk, fia eli-ne gum...

seek-HAB-PST.3SG-but very see-VN NEG

'Although they were searching (for the man), there was no finding' ("gab es kein Finden")

(Heeschen 2015: 343, no. 10)

The extension of the meaning of negated verbal nouns to impossibility can also be found elsewhere in languages of the Trans New Guinea phylum, for instance, in Wambon, as shown in (14).

(14) Digul Wambon: absolute negation

Sit indup $=e \quad$ aphinotopke- $l=0$

banana seedling=TOP be.dry.season-REAL $=$ CONNEC

sokmboghe-l=o lo-ndoi

become.dry-REAL=CONNEC plant-NEG

'As it was dry season, banana seedlings had withered and (people) could not plant (them).'

(Jang 2008: 53, quoted in Wester 2014: 136)

In Abau (Sepik) the existential negator lopa when following a verb and hereby nominalizing it "emphasises the absolute non-occurrence of the event over an extended period of time" (Lock 2011: 224). Abau absolute negation is always translated with 'never' in the examples, which suggests that it is more emphatic than in Eipo and Wambon. To what extent absolute negation is an areal phenomenon in New Guinea is a topic for further research.

Instances of the Eipo VERBAL NOUN + NEGATOR construction with explicit subjects, which are freely interchangeable with verbal negation as in (15), show that the VERBAL NOUN + NEGATOR construction has come a long way in competition with the symmetric verbal negation construction in Eipo. Symmetric negation seems to be less emphatic and is well suited for the repetition of information, as in (15): 
(15) Eipo: repeated negation, two different constructions ...el do bi-da kil do-m-uk, el wit 3SG first.born UNIQ-TOP woman take-PRF-PST.3SG 2SG younger.brother ara kil do-ne gum. Kil gum do-m-uk=nye TOP woman take-VN NEG woman NEG take-PRF-PST.3SG-NMLZ bi-rye... UNIQ-AGT

'The elder brother had taken a woman, the younger brother had not yet taken a woman. The one who had not taken a woman...'

(Heeschen 1990: 147, No. 15-16)

The standard negation construction gum V-INFL (38 occurrences) is roughly 2.5 times more frequent than VN gum (15 occurrences) in Heeschen (2015: 160-196), if prohibitive use is disregarded. VN gum AUX-INFL, to which we turn now, is clearly less frequent (4 occurrences). Negated verbal nouns with the auxiliary $u(b)$ - 'to be' are used in the same kind of contexts as impersonal sentence negation, as shown in (16):

(16) Eipo: negation with auxiliary, perfective

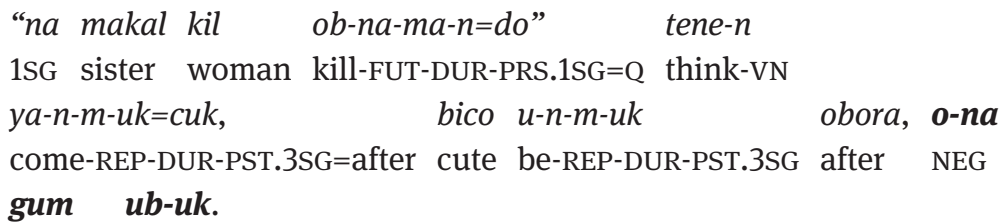

kill-vN be[PFV]-PST.3SG

'[When he saw that (that his sister had killed his wife)] he thought about killing his sister, but when he returned she was cute and nice and so there was no killing.'

(Heeschen 2015: 212, No. 13)

In (16) the auxiliary is inflected for perfective, in (17) for future tense and in (18) for habitual, always with the same form of the verbal noun. There is thus no parallel to the Nalca alternation in verb stems, which is a Nalca innovation (Section 4).

(17) Eipo: negation with auxiliary, future tense

Mane e-ne gum ub-nam-ne.

cuscus search-vN not be-FAR_FUT-PRS.1SG

'I will not look (or hunt) for cuscus.'

(Heeschen 1998: 263) 
(18) Eipo: negation with auxiliary, habitual

kil-ape gekeb-ik-ye-ora, ma-ne gum u-lam-ak. woman-PL hear-MED.3PL-CONNEC-when sleep-VN not be-HAB-PRS.3PL '[While they are fetching birds, they are standing, it dawns,] they hear the women, and they do not come to rest.'

(Heeschen 1998: 328)

Example (19) shows that the auxiliary can be emphasized by a proclitic ur'possibly, yes, other'.

(19) Eipo: auxiliary with emphatic particle ...sik basam di-ne gum. Basam di-ne gum ur=u-lam-ik. they pig eat-VN NEG pig eat-vN not EMPH=be-HAB-PST.3PL '[When they lived in the Bolbirye village,] they ate no pork. They ate no pork.' (Heeschen 2015: 416, no. 2-3)

As shown above, Eipo has the choice between different degrees of asymmetry in negation. There is the impersonal construction VERBAL NOUN + NEGATOR modelled on existential negation without person inflection (paradigmatically and syntagmatically asymmetric) and there is syntagmatically asymmetric, but paradigmatically symmetric construction VERBAL NOUN + NEGATOR + 'be'INFL where person inflection is reintroduced with an auxiliary. This choice between different degrees of asymmetry is unexpected in Miestamo's (2005) framework, who attributes the presence or absence of tense-aspect and person-number markers in the A/Fin type to the morpho-syntax of the verbal noun: "Which categories lose their marking in negatives [...] depends more on the general morphological characteristics of non-finite verbs in the language in question than on negation (and thus tells us less about negation than about non-finite verbs)" (Miestamo 2005: 158-159). Eipo, however, has the choice between symmetric negation and two different kinds of asymmetric negation, which reflects a diachronic development: (i) NEG V-INFL > (ii) V-VN NEG > (iii) V-VN NEG 'be'-INFL. Nalca verbal negation has developed from (iii) V-VN NEG 'be'-INFL. This presupposes a stage where (iii) has become the dominant option.

The reintroduction of tense and person marking happens in analogy to other non-inflected predicates, notably adjectives, exemplified in (20) with teleb 'good', which can both occur without a copula and - notably for the indication of low time stability - with the auxiliary $u(b)$ - 'be, live'. 
(20) Eipo: adjective without and with copula

Wa teleb ara, namin u-lam-uk obora, garden good TOP soft be-HAB-PST.3SG after tokwe teleb u-lam-uk obora "A-ub-n(a)-ab!" soil good be-HAB-PST.3Sg after here-be-FUT-PRS.1PL winyab-ik. say[PFV]-PST.3PL

'As to whether the garden was good, it was soft, the soil was soft, and then they said: "Let us live here!"'

(Heeschen 1998: 181)

According to Miestamo (2005: 206-208) the A/Fin Type reveals the stative character of negation in two different ways: (a) nouns are more time-stable than verbs in Givón's (1984) terms, and (b) the appearance of a stative copula is a clear indication of stativity. In Mek these two factors apply to two different subsequent stages. While it is true that the stative verb is an indication of stativity, the auxiliary does not motivate the appearance of the verbal noun construction in Mek in the first place. The verb is first nominalized (ii) and the copula is added only in a second step (iii). It is conceivable that the personless verbal noun construction could have expanded from absolute negation to all verbal negation uses. However, the introduction of person with the auxiliary in analogy to other non-inflected predicates facilitated the generalization to all verbal negation uses. Finally, (iii) -na gom $u(b)$ ) is too long for being used as frequently as verbal negation is and is fused to $-n g g u(b)$ - in Nalca. Which is where morphology takes over and analogy starts playing an even more important role.

\section{Morphological autonomy and diachony}

\subsection{Morphomic splits can arise from fusion and the morphome trap}

When V-VN NEG AUX-INFL fuses to V-NEG-INFL in Nalca, the structural differences that made verbal negation asymmetric - verbal noun and auxiliary - disappear. However, this does not render verbal negation automatically symmetric, and this is because Mek languages have different verb stems for different aspect-tense forms (see Table 5 in Section 2). The fusion of Nalca negation creates a morphomic 
split (Corbett 2016: 64; see also Section 1). I will argue here that Nalca cannot avoid a morphomic split and is caught in the morphome trap.

The stem in verbal negation originates from the verbal noun, which happens to be the same as in the imperfective, symbolized by "1" in Tables 7-9. Except for the negative potential, which has another origin that causes its stem to be the same as that of the future and perfective ("2"; see (11) in Section 3), we would expect all fused negation forms to have Stem 1 (Table 8). What we observe instead is the distribution in Table 9 with Stem 2 in many contexts where it is not expected. Section 4.2 will be devoted to explaining how the pattern in Table 9 has developed. The most important point, however, is that both the expected distribution - the one that would be there if no subsequent developments after fusion had taken place - and the observed distribution - with changes due to analogical adjustments - have morphomic splits. This is the morphome trap, which means that a morphomic split is hardly avoidable whatever adjustments are made.

Table 7: Nalca stems before fusion of negation.

\begin{tabular}{l|ccccccc|c|r}
\hline & VN & IPFV & IMP & PFV & FUT & POT & PERF & S_CVB & V $_{1}-l$ \\
\hline AFF & 1 & 1 & 2 & $2 b$ & 2 & 2 & 3 & 4 & 5 \\
\hline
\end{tabular}

Grey shade: inflected for person.

Table 8: Expected ( ${ }^{\star}$ reconstructed) distribution of stems after fusion of negation.

\begin{tabular}{|c|c|c|c|c|c|c|c|c|c|}
\hline$\star \star$ & VN & IPFV & IMP & PFV & FUT & РОт & PERF & S_CVB & $V_{1}-l$ \\
\hline AFF & 1 & 1 & 2 & $2 b$ & 2 & 2 & 3 & 4 & 5 \\
\hline NEG & & 1 & 1 & 1 & 1 & 2 & 1 & & \\
\hline
\end{tabular}

Grey shade: inflected for person, italics: asymmetric in suffixes.

Table 9: Observed distribution of stems after fusion of negation in Nalca.

\begin{tabular}{l|ccccccc|c|c|c}
\hline & VN & IPFV & IMP & PFV & FUT & POT & PERF & \multicolumn{2}{c}{ S_CVB } & V $_{\mathbf{1}}-l$ \\
\hline AFF & 1 & 1 & 2 & $2 b$ & 2 & 2 & 3 & 4 & 5 \\
NEG & & 1 & 1 & 2 & 2 & 2 & 2 & 2 & \\
\hline
\end{tabular}

Grey shade: inflected for person, italics: asymmetric in suffixes. 
Expected and observed distributions are both complex. However, the observed pattern differs from the expected pattern in that it is more symmetric in the forms where negation is inflected for person (grey shade in Tables 7-9). The same stem is used in both affirmative and negative in the perfective and in the future. Different stems only occur in the perfect.

Morphomes arguably existed already before the fusion of negation. Verbal noun and imperfective are no natural class together and neither are imperfective, perfective, future and potential. But the fusion of negation adds a new dimension to morphomes; it introduces a morphomic split. The example of Nalca negation shows that the morphologization of an originally syntactic category can be the source of a morphomic split in inflectional paradigms. This fact has not hitherto been considered in the literature on morphomes, which has failed to look for morphemes in the development of more synthetic paradigms. Maiden (2005) gives two sources for morphomes: (i) loss of an originally shared function, and (ii) loss of a phonological motivation. ${ }^{7}$

The classic example for (i), loss of an originally shared function, are the Spanish PYTA forms. In modern Romance languages forms deriving from the Latin perfect tend to share the same stem even though they do not express related functions any more. Spanish grammarians speak of perfecto y tiempos afines [PYTA-forms] 'perfect and related tenses', which are used in semantically so disparate forms as the past perfective indicative, the imperfect subjunctive and the future subjunctive, as in Spanish hubo [have.PST.PFV.3SG] 'had' and hubiese [have.SBJV.IPFV.3SG], to give an example for a verb to which the pattern has been extended by analogy.

A classic example for (ii), loss of a phonological motivation, is the L-shape in Ibero-Romance paradigms, illustrated in Section 1. In Romance languages an idiosyncratic set of present forms underwent palatalization. The L-pattern is operative even in cases where there was no palatalization originally (see Table 2 in Section 1).

I will argue in Section 4.2 that morphomic splits arising through synthesis are not just an additional type of morphome origin. Rather they have important bearings for the whole morphome debate. Based on morphomic splits from source (ii), loss of a phonological motivation, Corbett (2016: 75) argues that morphomic splits differ from motivated splits in optionality: "morphomic splits start out as obligatory and may become optional; motivated splits start out as optional and may become obligatory." It will be shown in Section 4.2 that the Nalca morphomic stems falsify this claim as they have become obligatory during their development in negation.

7 A third one, suggested by Maiden (2016: 44), is the transformation of one morphomic pattern to another. 


\subsection{The origins of the observed morphomic split in Nalca}

Tables 10 and 11 display selected finite and non-finite affirmative (top) and negative forms (bottom) for two verbs, where stems in some forms are fully symmetric (imperfective (3) and future (21)) and in some other forms fully asymmetric (perfect (22), imperative, and successive converb). The morphomic stems are labelled here IPFV\& stem (read "imperfective and others"; "1" in Tables 7-9) and PFV\& stem (read "perfective and others"; "2" in Tables 7-9). The labelling is arbitrary according to one aspect-tense form where the morphomes occur both affirmatively and negatively. The negative varieties of these two stems differ exclusively in that they mechanically add a euphonic empty morph -ne- if preceded by a consonant. ${ }^{8}$

Table 10: Nalca idiosyncratic distribution of the stems for 'go'.

\begin{tabular}{|c|c|c|c|c|c|}
\hline VN & Imperfective & Imperative & Future & Perfect & Success. converb \\
\hline \multirow[t]{2}{*}{$b a-n a^{\prime}$} & $b a-l a$ & bi-lom & bi-nim- [PFV\&] & bili-m- [PRF] & binib-oka [s_cvB] \\
\hline & ba-nggu-lum- & ba-nggom & bi-nggu-num- & bi-nggu-m- & bi-nggongom \\
\hline
\end{tabular}

Table 11: Nalca idiosyncratic distribution of the stems for 'put down, give birth'.

\begin{tabular}{lllllll}
\hline VN & Imperfective & Imperative & Future & Perfect & \multicolumn{1}{l}{ Success. converb } \\
\hline eili-na' & beilli-lam- [IPFV\&] & beib-lom & beib-nem- [PFV\&] & beiyi-m- [PRF] & beiyib-oka \$_CVB] \\
\cline { 2 - 2 } & beil(l)i- & beili- & beibne- & beibne- & beibne- \\
& nggu-lum- & nggom & nggu-num- & nggu-m- & nggongom \\
\hline
\end{tabular}

(21) Nalca: symmetric negation in future tense (with empty morph -ne-)

Na-ra Kristus a-dya aldib nong-nya ne-nye-k

1SG-TOP Christ DP-GEN real body-NMLZ N-DEM-DAT

leb-nam-na, na-ra sonda'

speak[PFV\&]-FUT-PRS.1SG 1SG-TOP false

lebne-nggu-num-na.

speak[N_PFV\&]-NEG-FUT-PRS.1SG

'I am telling the truth in Christ-I am not lying'

(N.T. 45009001)

8 According to Rule et al. (1972: 29) the vowel of the empty morph assimilates to the preceding syllable: buknu-nggu(b)- [sit-NEG-], mabna-nggu(b)- [lie-NEG-]. However, the orthography in the N.T. always has <e>. 
(22) Nalca: asymmetric negation in perfect aspect ...Yerusalem heik-ek bi-nggu-m-sa. [...] J. hamlet-LOC go[PFV\&]-NEG-PRF-PST.1SG

Arab soko-k sam bili-m-sa' ara...

Arab country-LOC at go[PRF]-PRF-PST.1SG:thing TOP 'nor did I go up to Jerusalem ... but I went away to Arabia...' (N.T. 48001017)

The stem in Nalca verbal negation derives from the verbal noun (see Section 3). In Mek there is a strong tendency for the verbal noun form and the -lam- (habitual > imperfective) aspect to share the same form. The N_IPFV\& forms are therefore easy to explain diachronically. They derive from the verbal noun and hence the vN stems and the N_IPFV\& stems in Table 12 are mostly identical (for -ne- see below). But where do the N_PFV\& forms come from? For most verbs they must have been created by analogy. However, analogy presupposes that some forms already exist as a link where the analogical development can start. Now it can be shown that there must have been verbal nouns for 'go' and 'come' with the stems $b i$ - and $y a$-, which are now the N_PFV\& stems in Nalca. Yale has the verbal nouns bin $(a)$ 'going' and yan 'coming' and Eipo has more conservative verbal noun forms bi-ne and ya$n e$ in the $\mathrm{V}_{1}-l \mathrm{~V}_{2}$ construction (Heeschen 1998: 178), where they supplete lacking forms with an $-l$ suffix, aside of Eipo bane 'going' and yangane 'coming'. In Nalca, the verbal noun for 'go' always has the stem $b a$-, but the N_PFV\& form bi-nggu- can have developed from ${ }^{*} b i$-na gum $u$ - [go-VN NEG be-]. The earlier stem variation in

Table 12: Nalca verb negative verb stems compared to verbal nouns and PFV\& stems.

\begin{tabular}{|c|c|c|c|c|c|}
\hline Verb type & VN & N_IPFV \& & N_PFV\& & PFV\& & \\
\hline$(C) \mathrm{V}(b)-$ & $l e-n a^{\prime}$ & le-nggu- & lebne-nggu- & leb- & 'speak' \\
\hline (C)ei(b/li/yi)- & eili-na' & eil(l)i-nggu- & eibne-nggu- & eib- & 'see' \\
\hline (C) $\mathrm{V} b(e)-$ & $g i b-n a^{\prime}$ & gibne-nggu- & gibne-nggu- & gib- & 'greet' \\
\hline (C) Vk(e)- & dek-na' & dekne-nggu- & dekne-nggu- & dek- & 'sell, pay' \\
\hline (C)VCV $(g a / k)-$ & elek-na' & elekne-nggu- & elega-nggu- & $\begin{array}{l}\text { elega- FUT } \\
\text { eleg(o)- PFV }\end{array}$ & 'give' \\
\hline (C)VCV(wa)- & sene-na' & sene-nggu- & senewa-nggu- & $\begin{array}{l}\text { senewa- FUT } \\
\text { sene- PFV }\end{array}$ & 'think' \\
\hline CV- & de-na' & de-nggu- & de-nggu- & de- & 'eat, drink' \\
\hline bi/ba/bili- & $b a-n a^{\prime}$ & ba-nggu- & bi-nggu- & $b i-$, by- & 'go' \\
\hline ya(ngga)/yeili- & $y a(n g g a)-n a^{\prime}$ & yangga-nggu- & ya-nggu- & $y a-$ & 'come' \\
\hline Suppl. he-/a- & (weny)a-na' & (weny)a-nggu- & (weny)he-nggu- & (weny)he- & 'say' \\
\hline
\end{tabular}


motion verbs (as it still exists in Eipo) served as a model for introducing perfective stems also for other verbs in the negative. If some verbs had two stems in negation which corresponded to imperfective and perfective in the affirmative, this model could also apply to all other verbs.

Another element that needs diachronic explanation is the empty morph -ne- occurring whenever the stem before the verbal noun suffix ends in a consonant both in N_IPFV\& and N_PFV\& stems (boldface in Table 12). This empty morph -ne- is nothing else than the verbal noun suffix diachronically. Before a following vowel, the verbal noun suffix was reduced to $-n$; before a consonant the vowel was retained. Such a phonological rule still exists in Nalca if the verbal noun is followed by a noun: "When a verbal noun [...] is linked with another noun which follows it, then the $-a$ is dropped if the $-n$ - is preceded by a vowel, but is retained if the $-n$ - is preceded by a consonant" (Rule et al. 1972: 56). Hence we can assume that the vowel of the suffix -na was not lost but only reduced, which yields *elekne-gu-lum- [GIVE-NEG-IPFV] for elek- 'give'. Since the negation morpheme had a nasal onset in all other forms, the velar nasal was reintroduced by analogy: *elek-ne-gu-> elek-nenggu-. This development gave rise to the empty morph -ne-, which is added before the negation morpheme after all stems ending in a consonant. The empty morph was also extended to N_PFV\& forms, which were created by analogy.

Aside from the secondary forms of verbal nouns of motion verbs, the negative potential forms may have played in when creating the Nalca negative PFV\& stems. Table 13 shows that they have the same form as the N_PFV\& stem, with the only difference that the euphonic element after consonant is -na-rather than -ne-.

Table 13: Nalca negative IPFV\& and PFV\& stems and negative potential forms.

\begin{tabular}{lllll}
\hline Verb type & NEG IPFV $\&$ & NEG PFV\& & N_POT & \\
\hline (C)V(b)- & do-nggu-lum- & dobne-nggu- & dobna-menggom & 'take' \\
(C)ei(b/li/yi)- & eili-nggu-lum- & eibne-nggu- & eibna-menggom & 'see' \\
(C)VCV(wa)- & unu-nggu-lum- & unuwa-nggu- & unuwa-menggom & 'do' \\
de- & de-nggu-lum- & de-nggu- & de-menggom & 'eat, drink' \\
da(nga)- & da(nga)-nggu-lum- & da-nggu-lum- & da-menggom & 'become' \\
bi/ba/bili- & ba-nggu-lum- & bi-nggu- & bi-menggom & 'go' \\
ya(ngga)/yeili- & yangga-nggu-lum- & ya-nggu- & ya-menggom & 'come' \\
Suppl. he-/a- & a-nggu-lum & he-nggu- & he-menggom & 'say' \\
\hline
\end{tabular}


As already mentioned in Section 3, the Nalca negative potential derives from the durative form of the verbal noun (see Example (11) for Eipo). The origin of the Nalca negative potential can be clearly seen in a comparison of Nalca (23) and Una (24) parallel examples. ${ }^{9}$

(23) Nalca: negative potential sik-ja dara, hweb-namenggom

3PL-ERG DS heal-N_POT

'... and they were not able to heal him.'

(N.T. 41009018)

The same construction, but without -na- is found in the Una N.T.

(24) Una (40017016): negated verbal noun in durative aspect

ni mi asi kweteb-ma-na kum kub-m-ang.

1SG son ACC heal-DUR-vN not be-DUR-PRS.3PL

'and they were not able to heal my son.'

The Nalca -na- element derives from the near future (future durative) -na-ma[FUT-DUR], as illustrated in (25) from Eipo with affirmative forms.

(25) Eipo: verbal noun in near future tense

Yume kwaning yongob-na-ma-n=sum babye,

first sweet_potato harvest-FUT-DUR-VN=day/when also

kwaning yongob-na-ma-n=talak ara, kil-ape gum

sweet_potato harvest-FUT-DUR-VN=when TOP woman-PL not

bik-lam-ak.

know-HAB-PRS.3PL

'The time of harvesting the first sweet potatoes, too, as to the time of harvesting (these) sweet potatoes the women do not know it.'

(Heeschen 1998: 189)

The rare Nalca affirmative suffix -namen also derives from this construction:

9 In Una there is often the auxiliary kub- 'be' whereas the Nalca negative potential form has the auxiliary only in 9 of 72 occurrences in the N.T. 
(26) Nalca: suffix deriving from verbal noun originally in near future tense beib-namen salek $^{10}$ anasa 'give_birth/put_down-NEAR_FUT_VN time when 'when about to giving birth'

(N.T. 66012002)

When the immediate future was lost as a morphosyntactic category along with the loss of the durative -ma-, the -namenggom-forms in the negative potential were redistributed by exaptation (Lass 1990) in analogy to the euphonic element -ne- in the verbal negation. The exaptation development can be summarized as follows: loss of the near future and durative categories, retention of their exponents in verbal nouns -na-ma- and -ma-, and redeployment in the negative potential with the same distribution as the empty morph -ne-in verbal negation.

Why could Nalca introduce the perfective stem into negation by analogy, but not the perfect stem, which remains restricted to the affirmative? The answer is that analogy needs links in order to become operative. For the perfective there were forms of the verbal noun that could be reanalyzed as perfective stems in negation (motion verbs) and there was a model in the negative potential. No such links were available for the perfect in negation. But why does the perfect have to maintain a stem of its own in the affirmative?

In Nalca there is a danger of homonymy between perfective (zero) and perfect because perfect morpheme $-m$ - is deleted if followed by a closed syllable: $m C V C>C V C$ (see Table 14). This is a strong motivation for keeping perfect and perfective stems different in the affirmative. Almost all Nalca verbs distinguish perfective and perfect stems even where Eipo and Yale do not (Eipo, Yale da[PFV/PRF] 'become', Nalca da- [PFV], danga- [PRF] 'become').

Table 14: Perfect and perfective forms with following closed syllables only distinguished by stems.

\begin{tabular}{lllll}
\hline & 'See' PRF PRS & 'see' PFV PRS & 'see' PRF PST & 'see' PFV PST \\
\hline 1SG & eiyi-m-na & eib-na & eiyi-m-sa & eib-sa \\
2SG & eiyi-lam & eib-lam & eiyi-lam & eib-lam \\
3SG & eiyi-m-la & eib-la & eiyi-m-ok & eib-uk \\
1DU & *eiyi-nam & eib-nam & eiyi-num & *eib-num \\
\hline
\end{tabular}

Forms with an asterisk are not attested in the N.T. and taken from Rule et al. (1972).

10 Nalca salek corresponds exactly to Eipo talak in (25). 
While the opposition between perfect and perfective in the affirmative is expressed by different stems, the distinction in negation is maintained by keeping the perfective negation asymmetric. In the perfective negation, the negation morpheme is -(ne)nggub-, testifying to the origin of the negation morpheme from the auxiliary construction with the prefective verb stem $u b$ - 'live, be' (see selected forms in Table 15).

Table 15: Perfect aspect unmarked if followed by a CVC sequence.

\begin{tabular}{|c|c|c|c|c|}
\hline & NEG PRF PRS & NEG PFV PRS & NEG PRF PST & NEG PFV PST \\
\hline $1 \mathrm{SG}$ & -nggu-m-na & $-n g g u-b-n a$ & -nggu-m-sa & $-n g g u-b-s a$ \\
\hline $2 S G$ & -nggu-lam & -nggu-b-lam & -nggu-lam & -nggu-b-lam \\
\hline $3 \mathrm{SG}$ & $-n g g u-m-l a$ & $-n g g u-b-l a$ & -nggu-m-ok & -nggu-b-[o/u]k \\
\hline 2DU & -nggu-rum & ${ }^{*}$-nggu-b-dum & -nggu-rum & ${ }^{*}$-nggu-b-dum \\
\hline
\end{tabular}

Forms with an asterisk are not attested in the N.T.

(27) Nalca: negative and affirmative perfective

sik-da yok nang dara, eibne-nggu-b-ek, 2PL-TOP other PL TOP see[PFV]-NEG-PFV-PST.3PL

bok Yesus ok eib-ik.

but Yesus only see[PFV]-PST.3PL

'they no longer saw anyone with them but Jesus alone'

(N.T. 41009008)

That the $-b$ - element is missing in the perfect aspect is expected as the perfect stem of 'be' is $u$-. In the future tense, however, where $-b$ - must have occurred originally, it is lost in the negative, which renders future negation fully symmetric. It remains unclear whether -nggu(b)- should be analyzed as -nggub- [NEG. PFV] or -nggu-b- [NEG-PFV] or -ngg-ub- [NEG-be[PFV]] (see Section 5.2 for further discussion).

The IPFV\& and PFV\& morphomes are not fully confined to inflection. Interestingly they lose their morphomic (idiosyncratic, meaningless) character when they are extended to derivation, where they become meaningful.

Together with the adverb anam 'still' the negative perfect is used to encode posterior subordinate clauses ('before S'), as shown in (28). In impersonal contexts, the suffix -nggom (originally verbal noun suffix plus negator), as in (29), is used instead. This is a negative adjective rather than an inflectional form of the 
verb. The derivational form in (29) is created in analogy to the inflectional form in (28). It takes its stem from the inflectional form where the stem is assigned mechanically (all negative perfect forms have the N_PFV\& stem) and it takes its specific 'not yet' meaning from the construction meaning in (28). This is how the morphome is resemantized in derivation - and hence ceases being a morphome when extended to derivation.

(28) Nalca: 'before S' construction with negative perfect Neyung o, soko anam u-yiwa-nggu-lum danyek... father VOC earth still be-CAUS[PFV\&]-NEG[PRF]-PST.2SG TOP 'Father, before you created the world...'

(N.T. 43017005)

(29) Nalca: negative adjective with the PFV\& stem meaning 'not yet'
Ban soko e-n
u-yiwa-nggom
salek e-nye-k...

DEM earth DN-DEM be-CAUS[PFV\&]-NEG time DN-DEM-DAT

'...from the foundation of the world'="at the time the world did not yet exist"

(N.T. 40025034)

The negative adjective with the meaning 'not yet' with the N_PFV\& stem, as for instance, in gela dobne-nggom-nya [woman take[PFV\&]-NEG-NMLZ] 'who has no wife, is not yet married' $(46,007,029)$ is opposed to the negative adjective lacking the 'not yet' meaning, where the original IPFV\& stem from the verbal noun is preserved, as in (30).

(30) Nalca: negative adjective with imperfective morphome
eili-nggom
heng $e-b$,
ke-nggom
o ne-b da-nye-k
See[IPFV\&]-NEG eye DN-COM hear[IPFV\&]-NEG ear N-COM PL-DEM-DAT
elegou-s-uk.
give[PFV]-OBJ.3-PST.3SG
'(God) gave them eyes that do not see and ears that do not hear.'
(N.T. 45011008)

The fact that morphomes can be resemantized in derivation is no argument against their existence in inflection.

The PFV\& stem was also extented to the negative successive converb formed with the suffix -nggonggom $[<\mathrm{VN}+$ gum + gum $]$ (see Section 5.2).

Let us now recapitulate the developments from the point of view of autonomous morphology. Before negation became inflectional in Nalca, there was 
already a morphosyntactially unmotivated association between stems in verbal nouns and stems of habitual/durative/imperfective -lam- forms, which, however, only partially extended to the irregular motion verbs. Negative forms deriving from verbal nouns of 'go' and 'come' could have two different stems and these were redistributed in the same way as in the affirmative. The potential negative forms developing from a different source, which happened to look as if they contained a perfective stem, also helped establishing perfective stems in the negative. Perfective stems were now also formed for all other verbs in negation by analogy, but other stem forms existing in the affirmative, such as the perfect stem and the converb stem, could not extend to the negative because there were no links to verbal noun forms that could be reanalyzed in such a way. This entailed an idiosyncratic distribution of stems, neither motivated by natural semantic classes nor by phonological conditions, i.e. a morphomic split. At the same time empty morphs, another hallmark of autonomous morphology, developed as a consequence of analogy and exaptation. Let us now consider whether there is any evidence whether the Nalca morphomic stems are attractors in the sense of Maiden (2005: 149).

Evidence for coherence of the morphomes comes from the fact that certain innovations are confined to morphomes. In Nalca and Yale 'say' became suppletive with the stem he- in Nalca being attracted by the PFV\& morphome (Table 16). For the verb $d a(n g a)$ - 'become', all forms of the PFV\& morphome resist to the introduction of the extension -nga- (Table 17).

Table 16: Nalca idiosyncratic distribution of the suppletive stems for 'say'.

\begin{tabular}{|c|c|c|c|c|c|}
\hline VN & Imperfective & Imperative & Future & Perfect & Success. converb \\
\hline \multirow[t]{2}{*}{$a-n a^{\prime}$} & a-lam- [IPFV\&] & he-lom & he-nem- [PFV\&] & $a-m-[\mathrm{PRF}]$ & $a b$-oka [S_CVB] \\
\hline & a-nggu-lum- & $a-n g g o m$ & he-nggu-num- & he-nggu-m- & he-nggongom \\
\hline
\end{tabular}

Table 17: Nalca idiosyncratic distribution of the stems for 'become'.

\begin{tabular}{|c|c|c|c|c|}
\hline VN & Imperfective & Future & Perfect & Success. converb \\
\hline \multirow[t]{2}{*}{$d a(n g a)-n a^{\prime}$} & \multirow{2}{*}{$\begin{array}{l}\text { da(nga)-lam- } \\
d a(n g a) \text {-nggu-lum- }\end{array}$} & \multirow{2}{*}{$\begin{array}{l}\text { da-nam- } \\
\text { da-nggu-num- }\end{array}$} & danga-m & dangaw-oka \\
\hline & & & \multicolumn{2}{|l|}{ da-nggu-m- } \\
\hline
\end{tabular}

The verbs for 'say' and 'become' are thus diachronic evidence for the coherence of the PFV\& and IPFV\& morphomes. These are attractors and not just diachronic relics. 
The negative forms are stricter in their adherence to the morphomic pattern than the affirmative forms. For 'come', the negative imperfective form is always yangga-nggu-, the verbal noun ya(ngga)-na' and the affirmative imperfective $y a$ (ngga)-lam- display variation. For 'go', the IPFV\& stem $b a$ - sometimes occurs even in PFV\& forms (ba-lom! [come[IPFV\&]-IMP.2SG] 4 occurrences vs. bi-lom! [come[PFV\&]-IMP.2SG] 66 occurrences 'go!'), but this variation is restricted to affirmative forms. This falsifies Corbett's (2016: 75) claim that morphomic splits cannot go from optional to obligatory. In the motion verbs 'go' and 'come' there was some variation in the use of stems before the fusion of negation and there is still some variation in the affirmative forms. In the negative forms, however, stems are strictly and obligatorily distributed according to the morphomic split.

While idiosyncratic in terms of natural morphosyntactic classes, morphomes are economic in that they make stem formation predictable (see also Maiden 2016: 62). They are a form of systematic syncretism for stems. After having encountered one form of a verb, all other forms belonging to the same morphome can be predicted. Now it may be argued that it would be simpler not to have any stems at all or to have motivated splits. However, as negation becomes inflectional, Nalca cannot avoid developing some sort of morphomic split since the affirmative forms fall into a number of several stems and since some of the affirmative stems are out of reach for analogical developments. This is the morphome trap. It is not that speakers would not try to make the system less complex. Speakers also manage to make the future tense fully symmetric and in the perfective at least the stems are the same in the affirmative and the negative. However, some kind of morphomic split is retained because any other option is out of reach without a complete destruction of the inflectional system.

Morphomes are not the only feature of autonomous morphology in Nalca negation. The euphonic elements -ne- and -na- are classic empty morphs (semantically empty, functionless morphemes; Maiden 2005: 166). Nalca is remarkable in that we can trace in detail how an inflectional pattern of negation with some of the hallmarks of autonomous morphology has emerged and it can be shown that autonomous morphology "need not be an inert, defunct, residue of an earlier état de langue, nor a kind of diachronic 'dead end”” (Maiden 2005: 168).

\subsection{A parallel case with differences in details: The fusion of negation in Wambon}

Nalca is not the only language of the Trans-New Guinea phylum with a rapid fusion of negation. It is instructive to consider the similarities and differences in the development of synthetic negation in the Aywu-Dumut language Wambon. 
Remember from Section 3 that Wambon, like Eipo and Yale, uses verbal nouns for the expression of impossibility. There is thus a parallel in the importance of absolute negation. Now, not unlike Mek, two different documented dialects of Wambon are also a parallel for a rapid morphologization of negation from an auxiliary construction. Yonggom Wambon has analytic negation (Table 18); Digul Wambon already has synthetic negation. What makes Wambon interesting for the morphome debate is that it has different stems for different tenses not unlike Mek. As in Nalca the fusion inevitably introduces a morphomic split and, as in Nalca, the observed distribution of stems is not the same as the expected distribution of stems (i.e. there were some subsequent developments beyond fusion) (Table 19). As in Nalca the stems are remotivated in some cells, in the case of Wambon this is the future tense (Table 20). Interestingly, this development is not paralleled by a development toward more symmetry in the future tense. The Digul Wambon negative future paradigm is syntagmatically highly asymmetric in the suffixes.

Table 18: Wambon stems before fusion of negation, Yonggom Wambon.

\begin{tabular}{l|c|c|c|c}
\hline & VN & \multicolumn{1}{c}{ PRS } & PST & FUT \\
\hline AFF & 1 & 1 & 2 & 3 \\
\hline
\end{tabular}

Grey shade: inflected for person.

Table 19: Expected (** ${ }^{\star}$ reconstructed) distribution of stems after fusion of negation.

\begin{tabular}{|c|c|c|c|c|}
\hline$\star \star$ & VN & PRS & PST & FUT \\
\hline AFF & 1 & 1 & 2 & 3 \\
\hline NEG & & 1 & 1 & 1 \\
\hline
\end{tabular}

Grey shade: inflected for person.

Table 20: Observed distribution of stems after fusion of negation in Digul Wambon.

\begin{tabular}{l|cc|c|c|c}
\hline & \multicolumn{2}{c}{ VN } & PRS & PST & \multicolumn{2}{c}{ FUT } & \multicolumn{1}{c}{ IMP } \\
\hline AFF & 1 & 1 & 2 & 3 & 1 or 4 \\
NEG & & 1 & 1 & 3 & 3 \\
\hline
\end{tabular}

Grey shade: inflected for person, italics: asymmetric in suffixes. 
In the small Wanik river variety of Wambon, Yonggom Wambon, negation is still clearly synthetic and of the asymmetric A/Fin type formed with a negative verbal noun suffix -nok and one of the auxiliaries mo- 'do' or ke- 'be':

(32) Yonggom Wambon

$\begin{array}{ll}\text { rap-nok } & \text { mo-gon-ep } \\ \text { take[BASIC]-N_VN } & \text { do-REAL-1SG } \\ \text { 'I did not take it.' } & \end{array}$

(Drabbe 1959: 140, quoted after Wester 2014: 135)

In Digul Wambon with fused negation, the "basic" form of the stem (en- eat[BASIC]), characteristic for present tense, is used even in past negation (ande- eat[PST]).

(31) Digul Wambon

a. e(n)-nok-ma-l-ep-o eat[BASIC]-N_VN-do[PST]-REAL-1SG-PST

'I did not eat.'

b. ande-l-ep-o

eat[PST]-REAL-1SG-PST

'I ate.'

(de Vries and Vries-Wiersma 1992: 35, 26; Wester 2014: 137):

Yonggom Wambon uses the same A/Fin auxiliary construction in the future tense as in other tenses. The Digul Wambon future tense, however, has a morphologized negation from another source: takhimo-khet-ndoi [buy[FUT]-SUPPORT.NON.1SG-NEG] 'he shall not buy' (according Wester's 2014: 138 analysis of Vries and Vries-Wiersma 1992: 36 petrified from a biclausal construction 'he shall buy, do it not'; Wester interprets -khet- as a petrified form of the support verb ke 'to be', but does not account for the negative imperative, which is just ande-khet! [eat[FUT]-SUPPORT. NON.1SG 'don't eat'). Given the short time Digul Wambon negation has had to become morphological and inflectional, the negative future paradigm is astonishingly complex. The first person singular form takhimo-ep-ep-ndoi [buy[FUT]-1SG-1SGNEG] 'I shall not buy' (with double person morpheme as in the affirmative) lacks the support element -khet-. Table 21 illustrates the morphomic split in Digul Wambon. ${ }^{11}$

The difference to Nalca is that the stem forms in Yonggom Wambon remain diachronically inert. Put differently, they cannot be proven to be morphomes in Maiden's $(2005,2016)$ sense, even though they are as much an instance of a

11 Stem formation is actually more complex since some verbs have special imperative stems and a special stem for past first person singular (Vries and Vries-Wiersma 1992: 24). 
Table 21: Morphomic split in the Digul Wambon stems for 'eat' and 'say'.

\begin{tabular}{ll|lll}
\hline & Present & Past & Future & Imperative singular \\
\hline AFFIRMATIVE & en-luk- & ande-lokha- & ande-lokho- & na-luk- \\
NEGATIVE & en-luk- & en-luk- & ande-lokho- & ande-lokho- \\
\hline
\end{tabular}

morphomic split in the sense of Corbett (2016) as Nalca. However, Yonggom Wambon and Nalca have in common that the morphomic split cannot be avoided and that attempts to get rid of it (remotivating the stems in some columns of the grid) do not lower the complexity of the system as a whole.

Both Nalca and Digul Wambon thus illustrate the morphome trap. After fusion the inflectional systems now including negation are caught in morphomic splits which are difficult to get rid of even if motivation of stem forms in some tense-aspect forms is reestablished.

A further parallel between Digul Wambon and Nalca is that the segmentation into morphemes and the semantic analysis of segmented elements is difficult. In the next section I will argue that this is a general characteristic of on-going fusion processes.

\section{Fragmentation of negation marking by fusion of constructions and by partial replacement}

\subsection{Introduction}

In Nalca there are several different negation morphemes instead of one general negator as in Eipo. Most of these have developed by way of a morphologization of negation constructions. Formally, this means fusion. But fusion is not only characterized formally. It also has a distinctive semantic property. In fusion the new morpheme takes over the original construction meaning. One way of understanding "today's morphology" as "yesterday's syntax" is thus to understand synthetic morphemes as fossilized constructions. This entails that fused morphemes can be very specialized in their meaning.

There are two major kinds of sources for new negation markers in Nalca: the gradual fusion of negation constructions originally containing the general negator gom, and the partial replacement by a new originally lexical element orok 'empty'. A third marginal source is expanded forms of the original general negator. Replacement contributes to fragmentation because it is only partial. 
This section traces the fragmentation of negation marking in Nalca. Section 5.2 addresses the gradual fusion of negation constructions into new specialized negation markers and 5.3 addresses the partial replacement. Section 5.4 puts the Nalca fragmentation of negation marking in a wider context.

\subsection{The gradual morphologization of negation constructions in Nalca}

Nalca has a whole set of different negation morphemes undergoing fusion from constructions with the general negator gom, the verbal negation morpheme -nggu- being just one of them. Fusion is a gradual process and the different kinds of negation are at various stages in the process of fusion depending on to what extent original morphemes are still transparent. While there is by definition change on the level of parts of the construction in fusion, construction meaning can remain constant. On-going fusion is characterized by unclear morpheme segmentation where various analyses are possible and where the morpheme meanings, however morphemes are segmented, are difficult to reconcile with Frege's Principle of Compositionality, according to which the meaning of the construction is determined by the meanings of its parts. Put differently, in the middle of the fusion process there is a primacy of construction meaning whereas before and after completed fusion, morpheme meaning is equally strong or stronger than construction meaning. As a consequence, reanalysis in fusion cannot be considered an abrupt process, but is gradual. After completed fusion, morphomic structures may arise (see Section 4). Hence there are two options, morpheme and morphome, after completed fusion. The development is summarized in Table 22.

I will now first discuss the constructions retaining largely constant construction meanings with decreasing degree of fusion and then address two constructions where the construction origin is more complex.

Table 22: Morpheme meaning and morpheme boundaries in different stages of fusion.

\begin{tabular}{cll}
\hline & Morpheme boundaries & Morpheme meaning \\
\hline Before fusion & Neat & Clear \\
On-going & Ambiguous, various analyses & Inconsistent, morpheme meaning difficult \\
$\begin{array}{c}\text { fusion } \\
\text { Completed }\end{array}$ & possible & to isolate \\
fusion & morphology & Clear (or none, if morphome) \\
\hline
\end{tabular}


While fusion in verbal negation in all tense-aspect forms except the perfective is completed with a neat reanalysis of - $n g g u$ - as verbal negator, the perfective aspect, where the form is V-nggub-INFL, remains partly ambiguous in its segmentation (-(ne)nggub- [N_PFV] -(ne)nggu-b- [NEG-PFV] -(ne)ngg-ub- NEG-be[PFV\&]]). This is an indication that fusion is not fully completed in the perfective aspect.

The negative potential for the expression of impossibility is also advanced in fusion. Etymologically -(na[FUTURE])-ma[DURATIVE]-ng[VERBAL.NOUN]-gom [GENERAL.NEGATOR], only gom can possibly be segmented with its original meaning in Nalca. The verbal noun suffix does not make sense synchronically in Nalca, since the PFV\& stem morphome occurs, the durative - $m a$ - is lost in Nalca and -na- has become a phonologically conditioned empty morph (see Section 4.2). The degree of fusion is lower than in verbal negation as the Nalca potential negative only sporadically occurs with a following auxiliary $u(b)$ - 'be' or da(nga)- 'become'.

Unlike the potential mood, the negative potential is not inflected for person, which makes it paradigmatically asymmetric. Its affirmative counterpart is the potential mood, which is formed with the future marker in the aspect tense slot and a special set of potential person-number suffixes, as shown in (33):

(33) Nalca: affirmative and negative potential

Al-ja pika bak-nam-so dara, nimi yok nang e-dya 3SG-ERG way open-FUT-POT.3SG TOP man other people DN-ERG serega-menggom, anya ono' al-ja serega-nam-so dara, close-N_POT PTC PTC 3SG-ERG close-FUT-POT.3SG TOP yok nang e-dya anaba bakna-menggom.

other people DN-ERG too close-N_POT

'the one who opens and no one can shut, and who shuts and no one can open' (N.T. 66003007)

The negative potential is not fully integrated into the paradigm, since the potential mood can also occur in the negative, but has then often a factive meaning, as in (34):

(34) Nalca: personal negative potential with factive meaning Im-ik Neyung a-k ab ya-nggu-m-so dara, sky-LOC father DP-DAT from come-NEG-PRF-POT.3SG TOP al-da yok- $a^{\prime}=y o k-a^{\prime} \quad$ unuwa-nggu-num-so 3SG-TOP other-thing=other-thing do-NEG-FUT-POT.3SG 'If this man were not from God, he would not be able to do anything!' (=But he is and hence he can.)

(N.T. 43009033) 
The Nalca prohibitive is basically still segmentable into V-ng-gom (mem) [V[IPFV\&]-VN-NEG (taboo)]. This lower degree of fusion is reflected in the two word orthography in Rule et al. (1972: 28): ong gvm 'don't hit', whereas the N.T. opts for univerbation. The compositionality is blurred because the prohibitive element -nggom is often reinforced by mem 'taboo', typically at least once in a sequence of several prohibitives, as in (35), which also allows for an analysis of -nggom as a co-prohibitive suffix.

(35) Nalca: prohibitive

...nimi salya' o-nggom, hoka' do-nggom mem, sonda' yuba men in_vain kill-PROH disposal take-PROH taboo, false word salya' le-nggom, anya an-ja' genonga neyung a-k pe in_vain say-PROH PTC 2SG-GEN mother father DP-DAT well gibe-l do-lolom.

greet-LNK take-IMP.2PL

'...do not murder, do not steal, do not give false testimony, honor your father and mother.'”

(N.T. 42018020)

This "double negation" in the prohibitive has clearly arisen from a fusion of two clauses "Do not do that! Forbidden!" as can be seen from the frequent use of a comma between -nggom and mem in the N.T. as in (36):

(36) Nalca: prohibitive

Anaso unu-nggom, mem!

like.this do-PROH taboo

'Do not do that!'

(N.T. 66022009)

Interestingly, Una has a prohibitive which diachronically lacks a negation morpheme, consisting of the medial inflection (co-subordination) followed by the connective - ye and the postposition -ak 'at' (>-i in Una), suggesting that it represents a case of insubordination (Evans 2007) - or, more precisely, in-cosubordination. A second clause mem 'it is taboo, forbidden' has to be reconstructed, which is elliptically omitted. ${ }^{12}$

12 Another possibility is the rare grammaticalization path: possibility>apprehension> warning > prohibition discussed by Pakendorf and Schalley (2007). 
(37) Una: prohibitive from in-co-subordination

...ilil kanya bob-mun-ye-i.

fear heart carry-MED.2PL-CONNEC-LOC

'Do not be afraid', literally: 'that you carry fear heart'

(N.T. 43012015)

In Eipo the corresponding construction is a polite affirmative imperative:

(38) Eipo: polite imperative with in-co-subordination

Ame ton areb-se-min-cuk

taro and give-OBJ.1PL-MED.2sG-after

Literally: 'Immediately after you have given us taro' i.e. 'Give us taro!', but the Eipo would never imperatively beg for taro.

(Heeschen 1998: 191)

Table 23 summarizes the diversity of Mek prohibitive constructions, all of which are asymmetric, whether inflected for person or impersonal.

Table 23: Mek prohibitive constructions.

\begin{tabular}{|c|c|c|c|}
\hline Eipo & $\mathrm{V}_{\mathrm{VN}}$-VN NEG/taboo & V-ne gum/mem & impersonal \\
\hline Una & $\mathrm{V}_{\mathrm{VN}}-\mathrm{VN}$ NEG/taboo & V-ng kum/-na mem & impersonal \\
\hline Una & $\mathrm{V}_{\mathrm{PFV}}$-MED-CONNEC-at & $\mathrm{V}-\min / d u m u n / m u n-y e-i[2 \mathrm{SG} / \mathrm{DU} / \mathrm{PL}]$ & person \\
\hline Nalca & $\mathrm{V}_{\mathrm{N}_{\text {IPFV \& }}}-$ nggom $(($,$) taboo )$ & V-nggom, mem & impersonal \\
\hline Nalca & $\mathrm{V}_{\text {IPFV\& }}$-VN TOP taboo & V-na' ara mem & impersonal \\
\hline Nalca & $V_{\text {N_PFVQ }}-N E G-F U T-P E R S$ & V-nggu-nu-lum/rum/lum [2SG/2DU/2PL] & person \\
\hline Yale & $\mathrm{V}_{\mathrm{PFV}}^{-}$-POT.3PL NEG & V-heng kom & always 3PL \\
\hline
\end{tabular}

Gom can be used as a suffix to verbal nouns for the formation of negative adjectives. In this function it is basically transparent, unless the PFV\& stem is used when the adjective has the connotation of 'not yet' (see Example (29) in Section 4.2). However, with the IPFV\& stem, this formation is rare (see Example (30) in Section 4.2) except for the lexicalized intensifier senenggom 'very', diachronically [think[IPFV\&]-VN-NEG] (compare, Swedish otroligt 'unbelievable > very').

Gom has the lowest degree of fusion when it negates nouns. However, in this function, it tends to be replaced by the emphatic form gom- $a$ [NEG-EMPH] or by a form with the suffixed thing nominalizer $-a^{\prime}$ : 
(39) Nalca: emphatic form goma in identity negation

ne-ra na gom-a!

this-TOP 1SG NEG-EMPH

'that one I am not'

(N.T. 42022058)

(40) Nalca: nominalized form goma'

Na-ra perob-nya gom- $a^{\prime}$ anasa 1SG-TOP good-NMLZ NEG-thing because 'because I am not the good/worthy one' (N.T. 40008008)

Left are a few occurrences of gom at the end of relative clauses in general nounmodifying clause constructions where the emphatic form and nominalized forms are not allowed. In the N.T. this is mainly the fixed expression Yahudi gom nim (i)/nang [Jews not men/people] 'people who are not Jews'.

Let us now consider two cases of partial fusion which are diachronically intransparent.

"Not know" is expressed in Nalca by the adjective elgom followed by $u(b)$ 'be' or da- 'become': elgom (u(b)-) [ignorant (be)] 'not know'. Its affirmative counterpart is ella $u(b)$ - [knowing be]:

(41) Nalca: 'know' and 'not know'

...elgom u-lum-na bok, Im-ik Neyung ok ella

ignorance be-IPFV-PRS.1SG but sky-LOC father only knowledge

u-lum-la.

be-IPFV-PRS.3SG

'...I do not know, God knows'

(N.T. 47012003)

The analysis of elgom 'not knowing' is ambiguously monomorphematic or bimorphematic (elgom el-gom). The affirmative is never ${ }^{*} e l$ in Nalca, but ella, but Yale has el 'knowing'. The Yale negative form ekon 'ignorant' is clearly monomorphematic: na ekon [I ignorant] 'I do not know'. Yale has the negator kom, not ${ }^{*} k o n$. This suggests that ekon has become Nalca el-gom [knowing-NEG] by folk etymology and in analogy to negative adjectives with the suffix -gom. Mek languages generally either express 'know' with a verb stem where negation is symmetric (Eipo bik- and Una bing- 'know') or with opposite adjectives (Eipo kel(e) 'wise, experienced', na walwal [I ignorant] 'I do not know'). 
Nalca has a specific negative successive converb with the suffix -nggongom (42), which is the negative counterpart to the successive converb with the suffix -oka (Eipo -uka, Una -oka) (43). No negative converb form is attested in Eipo, Yale or Una. In Eipo, the successive converb can be negated with a preposed or postposed general negator.

(42) Nalca: negative successive converb

...soruk mek elega-nggonggom de-lem-ak!

hand water give[N_PFv\&]-N_CvB eat-IPFV-PRS.3PL

'For they do not wash their hands when they eat a meal.'

(N.T. 40015002)

(43) Nalca: affirmative successive converb with backward spreading of negation

...soruk-a mek eleg-oka de-nggu-lum-ok-a' anasa... hand-EMPH water give-CVB eat-NEG-IPFV-PST.3SG-thing because 'that he did not first wash before the meal.'

(N.T. 42011038)

In both (42) and (43) the converb clause is negated semantically. In (43) there is a backward spreading of negation as it has been observed, for instance, also in Newari (Sino-Tibetan; Genetti 1986; Hale and Shrestha 2006: 187).

The form -nggongom must derive from the verbal noun suffix and twice the negator gom, the second one perhaps deriving from a one-word emphatic negative clause. The emphatic force is retained in the construction with the auxiliary described in Rule et al. (1972: 28A) for the expression of something which is never done. Rule et al. (1972) separate the second negator in orthography, which is an indication of a low degree of fusion.

(44) Nalca: emphatic double negative construction

sik-da kebne-ngvng gvm u-lum-ak

3PL-TOP listen[PFV\&]-VN:NEG NEG be[IPFV\&]-IPFV-PRS.3PL

'they never listen'

(Rule et al. 1972: 28A)

However, it is impossible to arrive at the meaning of (44) with a literal translation such as "they, there is no listening, no, they are", especially also given that the verb stem has the PFV\& morphome, which does not reflect the verbal noun (see Section 4.2). Whatever its specific origin, the Nalca negative successive converb represents an intermediate level of fusion. 
The Nalca negative converb is rare (only 34 tokens in the N.T. and much less frequent than the affirmative converb). Hence, its on-going fusion cannot be motivated by frequency. Rather its emergence can be understood only in the interplay of all other processes of morphologization of constructions of negation discussed in this section (summarized in Table 24).

Table 24: Different degrees of the advancement of fusion in Nalca negation constructions.

\begin{tabular}{lllll}
\hline & Nalca & N.T. & Rule et al. & Fusion \\
\hline Verbal negation & V-nggu-INFL & $\mathrm{xx}$ & $\mathrm{xx}$ & completed \\
Verbal negation PFV & V-ngg-u-b-INFL & $\mathrm{xx}$ & $\mathrm{xx}$ & almost completed \\
Neg. potential & V-(na)menggom & $\mathrm{xx}$ & not attested & almost completed \\
Neg. sequential converb & V-nggonggom & $\mathrm{xxx}$ & $\mathrm{xx} \mathrm{x}$ & on-going \\
Prohibitive & V-nggom $($ mem) & $\mathrm{xx}$ & $\mathrm{xx}$ & on-going \\
Neg. adjective & V-nggom & $\mathrm{xx}$ & not attested & on-going \\
Neg. noun predicate & $\mathrm{V}$ gom & $\mathrm{xx}$ & not attested & none \\
\hline
\end{tabular}

$\mathrm{x} \mathrm{x}$ : means that there is a space in orthography

We may conclude that Nalca shows a number of different, but parallel processes of gradual fusion of negation constructions to different negation morphemes. The least fused construction tends to be replaced with emphatic forms of the negator. Only in verbal negation - where the new negative morpheme ends up in the middle of the word - is fusion fully completed.

\subsection{Existential negation as a domain of its own}

The existence of special negative existentials is crosslinguistically common. They occur in $66 \%$ of Veselinova's (2013) world-wide sample. It is thus not astonishing that existential negation goes its own way when general negation is fragmentized. In this section it is shown that existential negation is independent as a domain not only in Nalca, but also elsewhere in Mek. New forms develop in Nalca and Yale for the negative existential, in Eipo, however, for the affirmative existential.

The Nalca existential negator orok is cognate to Yale odok 'nothing, empty' (wana odok [fruit/seed empty] 'an empty fruit or nut'), where it is a less frequent option for existential negation competing with kom. Eipo has oruk 'empty, barren' only in lexical function as a loan from the western languages (ninye oruk mok [man empty land] 'uninhabited place'; Heeschen and Schiefenhövel 
1983: 197). Nalca odok is also the short answer 'no!' (Eipo uses the general negator gum for 'no!'). Nalca gom becomes largely restricted to non-negative functions, to which it also has grammaticalized in Eipo and Una, notably disjunction and one of several question particles. This is illustrated in (45) with the disjunction (X gom X gom) and the short answer 'no!' orok:

(45) Nalca: disjunction gom and short answer 'no!' orok.

Yo gom, Orok gom, ok leb-lulum

yes or NEX or only say[PFV\&]-IMP.2PL

'But let your statement be 'Yes, yes; no, no,", literally "yes or no"

(N.T. 40005037)

Further non-negative functions of gum in Eipo are tag question and the introduction of utterances in a similar way as English well, in the beginning of direct speech (Heeschen 1998: 221-222).

(46) and (47) illustrate the different coding of existential ( $u(b)-$ 'be') and negative existentials (particle orok) in Nalca. (47) is predicative possession.

(46) Nalca: existential and negative existential

...Im-ik Neyung a-k al-ak hnonok ok u-lum-l-akanya, sky-LOC father DP-DAT 3SG-DAT one only be-IPFV-PRS.3SG-while

yok-nya ne-ra orok...

other-NMLZ N-TOP NEX

'...while there is only one God, there is nothing else.'

(N.T. 41012032)

(47) Nalca: existential and negative existential in predicative possession

Anasa hekne-dya ongo-n akleng penya u-lu-la-nya be-ra, PTC who-ERG wear-VN stringbag two be-IPFV-PRS.3SG-NMLZ M-TOP yok-nya ongo-n aklenga orok-nya be-k bok-oka,

other-NMLZ wear-VN stringbag NEX-NMLZ M-DAT share-CVB

hnon-da elek-le-lul.

one-TOP give-IPFV-IMP.3SG

'The one who has two tunics must share with the one who does not have one'

(N.T. 42003011)

Eipo, however, has an affirmative existential particle toba/tobe 'is there, is/are present' (Heeschen and Schiefenhövel 1983: 222). In the other Mek languages the cognate form is an adverb meaning 'continuously': Yale sob 'daily, often, 
steadily', Nalca soba' with negative inflection of the verb 'no longer, lit.: continuously not', Una tuba kum V 'no longer'. In Example (48) it can be seen how the existential sense may have developed from 'steadily':

(48) Eipo: existential from 'steadily'

Pesawat babye nun motokwe tobe, toba ya-nam-le...

plane also 1PL[POSS] mountain EX, steadily come-FUT-PRS.3SG nun=de imun gum. Imun ton un-e gum.

1PL=EMPH breathlessness NEG breathlessness one be-VN NEG

'Also the plane will be there, will steadily come to our mountains...We will not be afraid and timid, there will not be any fear or timidity'

(Heeschen 2015: 497, No. 13-14)

In the negative existential the copula may be present in Eipo as in (49), but in the affirmative existential after tobe it is usually lacking unless toba/tobe means 'still, always'.

(49) Eipo: negative existential with copula

Nay are kame-to-to gum u-lam-uk.

now TOP dog-like-like not be-HAB-PST.3SG

'At that time the dog people (those who were born by the dog: the Bolmerin people) did not exist.'

(Heeschen 1998: 201)

As in Eipo, in Nalca the negation of events can occasionally be expressed with the negative existential as in (50), especially in contrastive contexts:

(50) Nalca: verbal noun in negative existential construction ...hnon mek- $a^{\prime} \quad$ eili-na' orok bok, al-da Wenelesilnya Yesus one little-thing ${ }^{13}$ see-VN NEX but 3SG-TOP lord Jesus al-ja weis Yakobus be-k hnon-ok eib-sa. 3SG-GEN younger.brother Jacob M-DAT one-only see[PFV]-PST.1SG 'but I did not see any others of the apostles except James, the brother of the Lord.'

(N.T. 48001019)

Finally, Nalca orok can be used to reinforce sentence negation. This construction is rare.

13 Mek-a' little-thing, hnon mek- $a$ ' 'one little thing' and hnon 'one' add emphasis in negation. 
(51) Nalca: emphatic negation

Hyak unuwa-nggu-num-so, orok!

EMPH do-NEG-FUT-POT.3SG, NEX

'May it never be!'

(N.T. 45009014)

(52) Nalca: emphatic negation

ugun-uk elega-nggu-nu-s-ab, orok!

2PL-DAT give-NEG-FUT-OBJ.2PL-PRS.1PL NEX

'we will certainly not give it to you'

(N.T. 40025009)

Thus, while Nalca orok certainly has the potential for further extension in grammaticalization, its use remains so far quite limited when negation as a whole is considered.

We may conclude that affirmative and negative existential are two rather independent coding domains throughout Mek languages. This is well-in-line with Veselinova's (2013) finding that negative existentials are a typological domain of their own.

\subsection{Fragmentation of negation in a wider perspective}

It is crosslinguistically very common for languages to have special negators (such as Nalca) rather than one general negator (such as Eipo). As Wälchli (2014: 359) puts it, polymorphy, "the general tendency for meanings to be encoded by several different markers which also encode other meanings at the same time", is very common in negation. In many cases, polymorphy in negation is an effect of fragmentation of negation constructions by means of fusion, although not necessarily in the lexical verb. Modern Germanic languages have fused negative indefinite pronouns and adverbs. In Old High German it can be observed how standard negation tended to add a negative indefinite expression ni io wiht "not ever thing" for emphasis, which fused to the Modern German verbal negator nicht, and negative indefinite pronouns developed in concert with this development, while the Germanic preverbal negator $n i$ was gradually lost (Schrodt 2004: 135). English, which has undergone a similar development, is at present undergoing negation fusion in auxiliaries. In Mek languages, there are no negative indefinite pronouns (compare Example (33) for the expression of 'no one' with yok nang "other people" plus negation of the verb). The ways how negation can be fragmented are manyfold. On the one hand, general negators 
tend to be fragmented by fusion; on the other hand, general negators do not easily evolve from lexical sources, as negation markers originating from lexical sources do not instantly grammaticalize to general negators, but are first introduced into local negation domains, such as Nalca orok< 'empty' in the negative existential.

\section{The interaction of negative existential and verbal negation}

If not independent from verbal negation, negative existentials can be modelled as verbal negation (as in Finnish ei ole N [NEG.3SG be.CONEG] 'there is no N') or verbal negation can be modelled as negative existential (V-VN NEX as in Eipo with referential zeroing and absence of tense marking). There is a fourth option: NEG and NEX have the same form, which develops easily when a NEX morpheme replaces the NEG morpheme in emphatic use (nurturing the "constant and universal psycholinguistic proclivity for negative emphasizers"; Schwegler 1988: 36) and is then generalized to a general negator by inflationary use. This is summarized in Table 25.

Table 25: Possible relationships between negative existential and verbal negation.

\begin{tabular}{lllll}
\hline & $\begin{array}{l}\text { All verbal } \\
\text { negation }\end{array}$ & Independent & $\begin{array}{l}\text { Same } \\
\text { marker }\end{array}$ & $\begin{array}{l}\text { All negative } \\
\text { existential }\end{array}$ \\
\hline $\begin{array}{l}\text { Verbal negation } \\
\begin{array}{c}\text { Negative } \\
\text { existential }\end{array}\end{array}$ & NEG V(-INFL) & NEG VCOP(-INFL) N & $\begin{array}{l}\text { NEX N (or rarely } \\
\text { NEX V(-INFL) }\end{array}$ & NEX V-VN \\
$\begin{array}{c}\text { Type in Croft } \\
\text { (1991) }\end{array}$ & Type A & $\begin{array}{l}\text { Type B } \\
\text { Typ }\end{array}$ & Type C & Here: C2 \\
\hline
\end{tabular}

In an influential paper, Croft (1991) has argued that A (all verbal negation), B (independent), and C (same marker) form a dynamic negative-existential cycle (see also Veselinova 2016 for an elaboration of the model). B (independent) can arise from A (all verbal negation) by fusion (NEG-EX > NEX), C (same marker) can develop from $B$ as the existential negator is used as an emphatic verbal negator with subsequent weakening of the marker (NEX! V>NEG V), and A can develop from $\mathrm{C}$ by an analogical introduction of the affirmative existential marker into the negative existential construction (NEG VCOP N replaces NEG N). The full 
completion of the cycle "appears to occur very rarely within a period that allows for reasonable reconstruction” (Veselinova 2016: 141).

In Table 25 I postulate a fourth type C2 (all negative existential), which is accounted for by Croft (1991: 17), but not elaborated upon. At first glance it is similar with Croft's intermediate stage between $B$ and $C(B \sim C)$ "in which a special negative existential form begins to be used for ordinary verbal negation" (Croft 1991: 9). B C comes in various forms: (i) NEX can start replacing NEG and compete with it, (ii) NEX can reinforce NEG, and (iii) NEX can affect only part of the verbal system. However, $\mathrm{C} 2$ is like $\mathrm{C}$ in that the marker used is a general negator. The reason why verbal negation is substituted by existential negation is not the marker, but the construction, indicated by the fact that the verb appears in the form of a verbal noun. In the development from Mek to Nalca there is a development $\mathrm{C}>\mathrm{C} \sim \mathrm{C} 2>\mathrm{C} 2>\mathrm{B}$. Let us now look at the Mek constructions one-byone.

Eipo has arguably two verbal negation constructions: NEG V-INFL (Example (1)) and V-VN NEG (4). This can be solved, following Veselinova (2016: 147), by attributing the language to two different types at the same time. If we take gum V-INFL (1), the verbal negator is the same morpheme as the existential negator in N gum (8). Hence, this is type $C$. To the extent Eipo uses the copula in negative existentials as in (49), this can be considered a transitional stage to type A (C A), whereas A is never reached in any documented Mek language. If we count V-VN gum as verbal negation, it is derived from the existential negation construction and this is $\mathrm{C} 2$, or $\mathrm{C} \sim \mathrm{C} 2$ to the extent V-VN gum is not the dominant construction for verbal negation. For the development to Nalca we must reconstruct a stage where V-VN NEG be-INFL becomes the dominant verbal negation and this is stage C2. Nalca, however, has already different constructions for verbal negation (V-nggu-INFL (3)) and existential negation (N orok (46)). This is Type B. Since the existential negation can occasionally be used for verbal negation as well (V-VN orok (50)), there is arguably the very beginning of a transition from B to $\mathrm{C} 2$ in Nalca again, and the emphatic use of orok following bound verbal negation (V-nggu-INFL, orok (52)) is the beginning of B C (ii, reinforcement). This is all summarized in Table 26.

That B in Nalca develops without any intermediary stage A has two independent reasons:

(i) The new special existential negator did not develop from a fusion of an existential verb and a verbal negator, but rather has a lexical source. Such lexical sources are very common for existential negators crosslinguistically as shown by Veselinova (2013). Whenever a negative existential develops from a lexical source such as 'empty', Croft's cycle is reset to stage B. This is what happens in Yale where odok 'empty' competes with kom NEG in negative existentials. 
Table 26: The types of existential negation in Mek.

\begin{tabular}{llll}
\hline & Verbal negation & Negative existential & Type \\
\hline Eipo & gum V-INFL & $\mathrm{N}$ gum & $\mathrm{C}$ \\
Eipo (minor) & gum V-INFL & $\mathrm{N}$ gum 'be'-INFL & $\mathrm{C} \sim \mathrm{A}$ \\
Eipo (minor) & V-VN gum & $\mathrm{N}$ gum & $\mathrm{C} \sim \mathrm{C} 2>\mathrm{C} 2$ \\
Eipo (rare) & V-VN gum u-'be'-INFL & $\mathrm{N}$ gum & $\mathrm{C} \sim \mathrm{C} 2>\mathrm{C} 2$ \\
Yale & V-INFL kom & $\mathrm{N}$ kom & $\mathrm{C}$ \\
Yale (minor) & V-INFL kom & $\mathrm{N}$ odok & $\mathrm{B}$ \\
Nalca & V-nggu-INFL & $\mathrm{N}$ orok & $\mathrm{B}$ \\
Nalca (rare) & V-VN orok & $\mathrm{N}$ orok & $\mathrm{B} \sim \mathrm{C} 2$ \\
Nalca (rare) & V-nggu-INFL, orok & $\mathrm{N}$ orok & $\mathrm{B} \sim \mathrm{C}$ \\
\hline
\end{tabular}

(ii) In Nalca, there was never a verb added by analogy in the negative existential. Rather a verb was added in the verbal negation: the auxiliary $u(b)$ - 'be' (VVN NEG 'be'-INFL > V-NEG-INFL), and it is the fusion of this construction to a separate verbal negation morpheme that dissociates the verbal negation from existential negation. Disruption would have taken place even if Nalca had not replaced gom by odok in the existential negation domain.

Interestingly, the same three processes as in Croft's cycle - loss of expressivity, analogy, and fusion - are also involved in the Nalca development in the same order (see Table 27):

Table 27: Loss of expressivity, analogy and fusion in different developments.

\begin{tabular}{lll}
\hline Loss of expressivity & Analogy & Fusion \\
\hline $\begin{array}{l}\text { Croft (1991) } \\
\text { B }>\text { C }\end{array}$ & C $>$ A & A $>$ B \\
NEX! V $>$ NEG V & NEG VCOP N replaces & NEG-EX \\
& NEG N & $>$ NEX \\
Mek $>$ Nalca & & \\
C $>$ C C2 & C $\sim 22>C 2$ & C2 $>$ B \\
Negative existential construction (V-VN NEG) & V-VN NEG 'be'-INFL & VN-NEG-AUX \\
increasingly used for verbal negation & replaces V-VN NEG & $>$ NEG \\
\hline
\end{tabular}

The use of verbal nouns in existential constructions especially in potential, habitual and prohibitive contexts (o-ne gum [kill-vN NEG] 'there is no killing' > (he) could not kill (any), they do not usually kill, don't kill') is generalization with loss of expressivity ( $\mathrm{C} \sim \mathrm{C} 2$ ), although emphasis is not the only reason to introduce a negative existential construction. Further motivations are 
the stative character of negation (Miestamo 2005: 206-208) and referential zeroing (Heeschen 1998: 263).

It must be added that loss of expressivity and analogy also appear elsewhere in the development. Loss of expressivity is involved when the general negator gom in Nalca disappears from all negation domains and is restricted to disjunction, question particles and tag questions (Section 5.2). Analogy is the driving force for establishing the PFV\& stem in negation (Section 4.2).

While I agree with Croft (1991) that fusion, emphasis/weakening and analogy are central processes in the evolution of negation marking, I do not find any evidence that these processes may be exclusively claimed by particular functionally motivated constellations. In Nalca fusion occurs in verbal negation and not in existential negation and analogy has highly idiosyncratic properties which can hardly be generalized to a crosslinguistic typology as, for instance, when the alternation of -ne and $-n$ in verbal noun suffix gives rise to an empty morph -ne and as synchronically unanalyzable durative future stems are identified with that empty morph (see Section 4.2).

While it is certainly true that it is always diachronic processes that underlie actually existing language types (Croft 1991: 24), it is not the case that certain diachronic processes can always be directly inferred from synchronic types.

\section{Conclusions}

How does synthetic negation arise from analytic negation? Words are not easily inserted in the middle of other words. But today's morphology is often yesterday's syntax, and this holds for the synthetic verbal Nalca negation, which has arisen from the fusion of a construction consisting of the verbal noun, 'not(hing)', and an inflected auxiliary. This is how 'nothing' easily moves to the middle of the verb, ending up in the position immediately following the verb stem, a crosslinguistically preferred position for negation markers. From the perspective of (a)symmetry of negation construction in Miestamo's (2005) terms, however, things are more intricate. Although initial and terminal stages of the process are symmetric or largely symmetric, the intermediate stages are asymmetric. A further complicating factor is that what at first glance just looks like grammaticalization is in fact partly due to analogy, the process that Meillet (1948 [1912]) said it was insufficient for explaining the emergence of grammar when he coined the term grammaticalization. But if morphology is yesterday's syntax, does this mean that it is just a more 
condensed kind of syntax? No. Morphology is autonomous. It has its own - purely morphological - units, which do not sort into natural morphosyntactic classes. When Nalca negation becomes inflectional, it develops morphomes and empty morphs. If morphology is yesterday's syntax, do syntactic and morphological morphemes have the same kind of meaning? No. In the process of fusion, morpheme meaning is lost and replaced by construction meaning. The meaning of synthetic morphemes is thus reanalyzed construction meaning, which is why the meaning of synthetic grammatical morphemes can be more specific than the meaning of grammatical words. But what gets grammaticalization going in the first place? Why does negation easily become synthetic in Nalca? The development must somehow be triggered and there must be a semantic niche which has a potential to expand later. This niche, absolute negation, can be identified in discourse in a neighboring language, Eipo, which has remained more conservative. The reason why this can be traced is that Eipo happens to be one of the best documented languages of New Guinea, thanks to the work by Volker Heeschen. Couldn't we have guessed it all from interpolating over well-known recurrent developments in verbal and existential negation as Croft (1991) has shown us? We could have guessed part of it. It is also no suprise that we find similar developments in another language of the area, Wambon, where a similar trigger seems to have kicked off similar developments (Wester 2014: 134-138). But for some details, such as the development of morphomes, it is essential that they are idiosyncratic and not crosslinguistically recurrent, and hence cannot be reconstructed without solid documentations and traditional historical linguistics. What do we miss if we miss the details? That language change is historical in the sense of that it is as specific as it is general.

Acknowledgements: I would like to thank Volker Heeschen, Ljuba Veselinova, Johan van der Auwera, Östen Dahl, Sebastian Fedden, Bruno Olsson, Henrik Bergqvist, and two anonymous reviewers for many useful comments on earlier versions of this work. I am very grateful to all the people who have documented the Mek languages: Volker Heeschen, Samuel Souga, Jeremy Souga, Roger Doriot, John Binzell, John Louwerse, Dick Kroneman, W. M. Rule, J. E. Rule, R. Cutting and others. The permission of the Indonesian Bible Society to use the Una N.T. is gratefully acknowledged. While writing this paper I was funded by the Swedish Research Council (Vetenskapsrådet, 421-2011-1444). 


\section{Appendix A. Data sources: Bible translations}

Nalca New Testament. n.d. Translated by Samuel and Jeremy Souga and Roger Doriot.

Una New Testament. 2007. Translated by Wilem Balyo, Titus Bitibalyo, Melkias Kipka and Gipson Malyo, with consultant input from Dick and Margreet Kroneman (SIL) and Lourens de Vries (UBS).

\section{Appendix B. Abbreviations in glosses}

1 first person, 2 second person, 3 third person, A agent-like argument of canonical transitive verb, ACC accusative, AFF affirmative, AGT agentive, BASIC basic stem (Wambon), CAUS causative, COM comitative, CONEG conegative form of the verb, CONNEC connective, CVB converb, DAT dative, DEM demonstrative, DN default noun gender (Nalca), DP default phrase gender (Nalca), DS different subject, DU dual, DUR durative, ERG ergative, EMPH emphasis, EX esistential, FAR_FUT far future, FUT future, GEN genitive, HAB habitual, IMP imperative, INFL inflection, IPFV imperfective, IPFV\& morphome covering imperfective among other things (Nalca), LNK linker $-l$ in sequences of verb stems (Nalca), LOC locative, M masculine, N neuter, $\mathrm{N}_{-}$negative, NEG negation, NEX negative existential, NEX! negative existential in emphatic use, NMLZ nominalizer, MED sentence-medial person-number markers, NOM nominative, OBJ object, $\mathrm{P}$ patient-like argument of canonical transitive verb, PFV perfective, PFV\& morphome covering perfective among other things (Nalca), PL plural, POSS possessive, POT potential mood, PRF perfect, PRS present, PROH prohibitive, PST (remote) past, PTC particle, Q question particle, REAL realis, REP repetitive (stem extension), $S$ single argument of canonical intransitive verb, S_CVB sequential converb, SBJV subjunctive, SG singular, SIM_CVB simultaneous converb, TOP topic, UNIQ uniqueness (Una, Eipo), Voc vocative, VN verbal noun

\section{References}

Aronoff, Mark. 1994. Morphology by itself. Cambridge, MA: MIT Press.

Binzell, John. n.d. Nalca original texts. 8 texts collected by John Binzell around 1975. 16 pages, unpublished manuscript.

Bybee, Joan. 1985. Morphology: A study of the relation between meaning and form, (Typological Studies in Language 9.). Amsterdam \& Philadelphia: John Benjamins. 
Comrie, Bernard, Diana Forker, \& Zaira Khalilova. 2013. Generalized noun-modifying clause constructions in Bezhta and Hinuq (Nakh Daghestanian). Paper presented at the 10th Meeting of the Association for Linguistic Typology, Leipzig, 17 August.

Corbett, Greville G. 2016. Morphomic splits. In Ana R. Luís \& Ricardo Bermúdez-Otero (eds.), The morphome debate, 64-88. Oxford: Oxford University Press.

Croft, William. 1991. The evolution of negation. Journal of Linguistics 27. 1-39.

Dahl, Östen. 1979. Typology of sentence negation. Linguistics 17. 79-106.

Drabbe, Petrus. 1959. Kaeti en Wambon, twee Awyu dialecten. 's Gravenhage: Nijhof.

Eibl-Eibesfeldt, Irenäus, Wulf Schiefenhövel, \& Volker Heeschen. 1989. Kommunikation bei den Eipo: Eine humanethologische Bestandesaufnahme, (Mensch, Kultur und Umwelt im zentralen Bergland von West-Neuguinea 19.). Berlin: Reimer.

Evans, Nicholas. 2007. Insubordination and its uses. In Irina Nikolaeva (ed.), Finiteness: Theoretical and empirical foundations, 366-431. Oxford: Oxford University Press.

Genetti, Carol. 1986. Scope of negation in Newārī clause chains. Paper presented at the 19th annual meeting of the International Conference on Sino-Tibetan Languages and Linguistics, Ohio State University, Columbus, Ohio, September.

Givon, Talmy. 1971. Historical syntax and synchronic morphology: An archeologist's field trip. Chicago Linguistic Society 7. 391-415.

Givón, Talmy. 1984. Syntax: A functional-typological introduction. Vol. 1. Amsterdam \& Philadelphia: John Benjamins.

Güldemann, Tom. 1999. The genesis of verbal negation in Bantu and its dependency on functional features of clause types. In Jean-Marie Hombert \& Larry M. Hyman (eds.), Bantu historical linguistics: Theoretical and empirical perspectives, 545-587. Stanford, CA: Center for the Study of Language and Information.

Hale, Austin, \& Kedār P. Shrestha. 2006. Newār (Nepāl Bhāsā). Munich: Lincom.

Hammarström, Harald, Robert Forkel, Martin Haspelmath, \& Sebastian Bank 2016. Glottolog 2.7. Jena: Max Planck Institute for the Science of Human History. www.glottolog.org

Haspelmath, Martin. 1998. Does grammaticalization need reanalysis?. Studies in Language 22(2). 315-351.

Heeschen, Volker. 1990. Ninye bún: Mythen, Erzählungen, Lieder und Märchen der Eipo im zentralen Bergland von Irian Jaya (West-Neuguinea), Indonesien, (Mensch, Kultur und Umwelt im zentralen Bergland von West-Neuguinea 20.). Berlin: Reimer.

Heeschen, Volker. 1992a. A dictionary of the Yale (Kosarek) language (with sketch of grammar and English index), (Mensch, Kultur und Umwelt im zentralen Bergland von WestNeuguinea 22.). Berlin: Reimer.

Heeschen, Volker. 1992b. Review of J. Louwerse. The Morphosyntax of Una in Relation to Discourse Structure. Language and Linguistics in Melanesia 23(1). 63-68.

Heeschen, Volker. 1998. An ethnographic grammar of the Eipo language spoken in the central mountains of Irian Jaya (West New Guinea), Indonesia, (Mensch, Kultur und Umwelt im zentralen Bergland von West-Neuguinea 23.). Berlin: Reimer.

Heeschen, Volker. 2000. Die Yale-Sprache, eine Papua-Sprache. In Ludger Hoffmann (ed.), Sprachwissenschaft: Ein Reader, 2nd edn., 759-774. Berlin \& New York: Mouton de Gruyter.

Heeschen, Volker. 2015. Die Eipo in Papua: Weltbilder, Ethnographie und Erzählungen. Munich: Ludwig-Maximilians-Universität. [In Zusammenarbeit mit Yakob Bolmerin, Laik Malyo, Eneneas Malyo, Enus Nabyal und Filipus Nabyal] (Studien aus dem Münchner Institut für Ethnologie 19) https://epub.ub.uni-muenchen.de/25303/. 
Heeschen, Volker, \& Wulf Schiefenhövel. 1983. Wörterbuch der Eipo-Sprache. Eipo - Deutsch Englisch, (Mensch, Kultur und Umwelt im zentralen Bergland von West-Neuguinea 6). Berlin: Reimer.

Jang, HongTae. 2008. Morphology and syntax of Wambon, a grammar sketch. Indonesia: SIL unpublished $\mathrm{ms}$.

Kroneman, Dick. 2004. The LORD is my shepherd: An exploration into the theory and practice of translating biblical metaphor. Amsterdam: Vrije Universiteit Amsterdam dissertation.

Lass, Roger. 1990. How to do things with junk: Exaptation in language evolution. Journal of Linguistics 26. 79-102.

Lock, Arnold (Arjen) Hugo. 2011. Abau grammar (Data Papers on Papua New Guinea Languages 57). Ukarumpa. Papua New Guinea: SIL-PNG Academic Publications.

Louwerse, John. 1988. The morphosyntax of Una in relation to discourse structure: A descriptive analysis, (Pacific Linguistics B100). Canberra: The Australian National University.

Lüdtke, Helmut. 1980a. Sprachwandel als universales Phänomen. In Helmut Lüdtke (ed.), Kommunikationstheoretische Grundlagen des Sprachwandels, 1-19. Berlin \& New York: De Gruyter.

Lüdtke, Helmut. 1980b. Auf dem Weg zu einer Theorie des Sprachwandels. In Helmut Lüdtke (ed.), Kommunikationstheoretische Grundlagen des Sprachwandels, 182-252. Berlin \& New York: De Gruyter.

Luís, Ana R., \& Ricardo Bermúdez-Otero (eds.). 2016a. The morphome debate: Diagnosing and analysing morphomic patterns. Oxford: Oxford University Press.

Luís, Ana R., Ricardo Bermúdez-Otero (eds.). 2016b. The morphome debate, 309-340. Oxford: Oxford University Press.

Maiden, Martin. 2005. Morphological autonomy and diachrony. In Geert Booij \& Jaap van Marle (eds.), Yearbook of morphology (2004), 137-175. Dordrecht: Springer.

Maiden, Martin. 2016. Some lessons from history. Morphomes in diachrony, 33-63. In Ana R. Luís \& Ricardo Bermúdez-Otero (eds.), The morphome debate, 309-340. Oxford: Oxford University Press.

Meillet, Antoine. 1948 [1912]. L'évolution des formes grammaticales. In Antoine Meillet (ed.), Linguistique historique et linguistique générale 1, 130-148. Paris: Edouard Champion.

Miestamo, Matti. 2005. Standard negation: The negation of declarative verbal main clauses in a typological perspective. Berlin \& New York: Mouton de Gruyter.

Pakendorf, Brigitte, \& Ewa Schalley. 2007. From possibility to prohibition: A rare grammaticalization pathway. Linguistic Typology 11. 515-540.

Rule, W. M., J. E. Rule, \& R. Cutting, 1972. Hmanggona Language of the Naltja Area. Irian Barat (A member of the Goliath Family of languages, previously called Kimjal by Mr S. Sadlier). Naltja; Statement of the Alphabet \& Grammar.

Schrodt, Richard. 2004. Althochdeutsche Grammatik II: Syntax. Tübingen: Niemeyer.

Schwegler, Armin. 1988. Word-order changes in predicate negation strategies in Romance languages. Diachronica 5. 21-58.

Svärd, Erik. 2013. Selected topics in the grammar of Nalca. Stockholm: Stockholm University.

Veselinova, Ljuba N. 2013. Negative existentials: A crosslinguistic study. Italian Journal of Linguistics 25. 107-146.

Veselinova, Ljuba N. 2016. The negative existential cycle viewed through the lens of comparative data. In Elly van Gelderen (ed.), Cyclical change continued, 139-187. Amsterdam \& Philadelphia: Benjamins. 
Vries, Lourens de. 2007. Some remarks on the use of Bible translations as parallel texts in linguistic research. Sprachtypologie und Universalienforschung (STUF) 60(2). 148-157.

Vries, Lourens de, \& Robinia de Vries-Wiersma. 1992. The morphology of Wambon of the Irian Jaya Upper-Digul area: With an introduction to its phonology. Leiden: KITLV Press.

Wälchli, Bernhard. 2014. Algorithmic typology and going from known to similar unknown categories within and across languages. In Benedikt Szmrecsanyi \& Bernhard Wälchli (eds.), Aggregating dialectology, typology, and register analysis: Linguistic variation in text and speech, 355-393. Berlin \& Boston: De Gruyter.

Wälchli, Bernhard. 2018. The rise of gender in Nalca (Mek, Tanah Papua): The drift towards the canonical gender attractor. In Sebastian Fedden, Jenny Audring \& Corbett Greville (eds.), Non-canonical gender systems, 68-99. Oxford: Oxford University Press.

Wester, Ruth. 2014. A linguistic history of Awyu-Dumut: Morphological study and reconstruction of a Papuan language family. Amsterdam: Vrije Universiteit Amsterdam dissertation. 